\title{
Providing Solutions to Energy and Environmental Programs
}

\author{
Quarterly Report
}

October 1 - December 31, 1996

\author{
PEC \\ MP 311997 \\ Work Performed Under Contract No.: DE-FC21-93MC30127 \\ OSTI \\ For \\ U.S. Department of Energy \\ Office of Fossil Energy \\ Morgantown Energy Technology Center \\ P.O. Box 880 \\ Morgantown, West Virginia 26507-0880
}

By

Western Research Institute 365 North Ninth Street

Laramie, Wyoming 82070

HH 


\section{DISCLAIMER}

This report was prepared as an account of work sponsored by an agency of the United States Government. Neither the United States Government nor any agency thereof, nor any of their employees, makes any warranty, express or implied, or assumes any legal liability or responsibility for the accuracy, completeness, or usefulness of any information, apparatus, product, or process disclosed, or represents that its use would not infringe privately owned rights. Reference herein to any specific commercial product, process, or service by trade name, trademark, manufacturer, or otherwise does not necessarily constitute or imply its endorsement, recommendation, or favoring by the United States Government or any agency thereof. The views and opinions of authors expressed herein do not necessarily state or reflect those of the United States Government or any agency thereof.

Available to the public from the National Technical Information Service, U.S. Department of Commerce, 5285 Port Royal Road, Springfield, VA 22161; phone orders accepted at (703) 487-4650.

This report has been reproduced directly from the best available copy. 


\section{DISCLAMIER}

Portions of this document may be illegible in electronic image products. Images are produced from the best available original document. 


\section{Table of Contents}

Program Overview 1

Summary of Appropriations, Obligations \& Expenditures 2

$\begin{array}{ll}\text { Executive Summary } & 3\end{array}$

$\begin{array}{ll}\text { Current Obligations } & 4\end{array}$

$\begin{array}{ll}\text { Current Expenditures } & 7\end{array}$

$\begin{array}{lr}\text { Technical Highlights } & 8\end{array}$

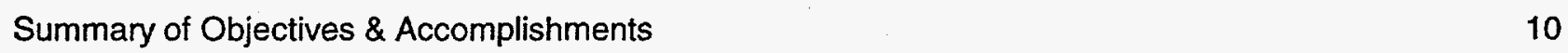

Task 001 Development and Demonstration of a Practical Electric

Downhole Steam Generator for Thermal Recovery of Heavy Oil and Tar 11

Task 002 Wetting Behavior of Selected Crude Oil/Brine/Rock Systems 14

Task 003 Coal Gasification, Power Generation and

Product Market Study

Task 004 The Impact of Leachate from Clean Coal Technology Waste on the Stability of Clay Liners

Task 005 Investigation of Coprocessing Heavy Oil, Automobile

Shredder Residue, and Coal

Task 006 Injection into Coal Seams for Simultaneous $\mathrm{CO}_{2}$ Mitigation and Enhanced Recovery of Coalbed Methane

Task 007 Optimization of Carbonizer Operations in the FMC Coke Process 23

Task 008 Chemical Sensor and Field Screening Technology Development 24

Task 009 Demonstration of the Koppelman "Series C" Process Using a Batch

Test Unit with Powder River Basin Coal as Feed

Task 010 (Old Task 5.25) Remote Chemical Sensor Development

Task 011 Market Assessment and Technical Feasibility Study of PFBC Ash Use 


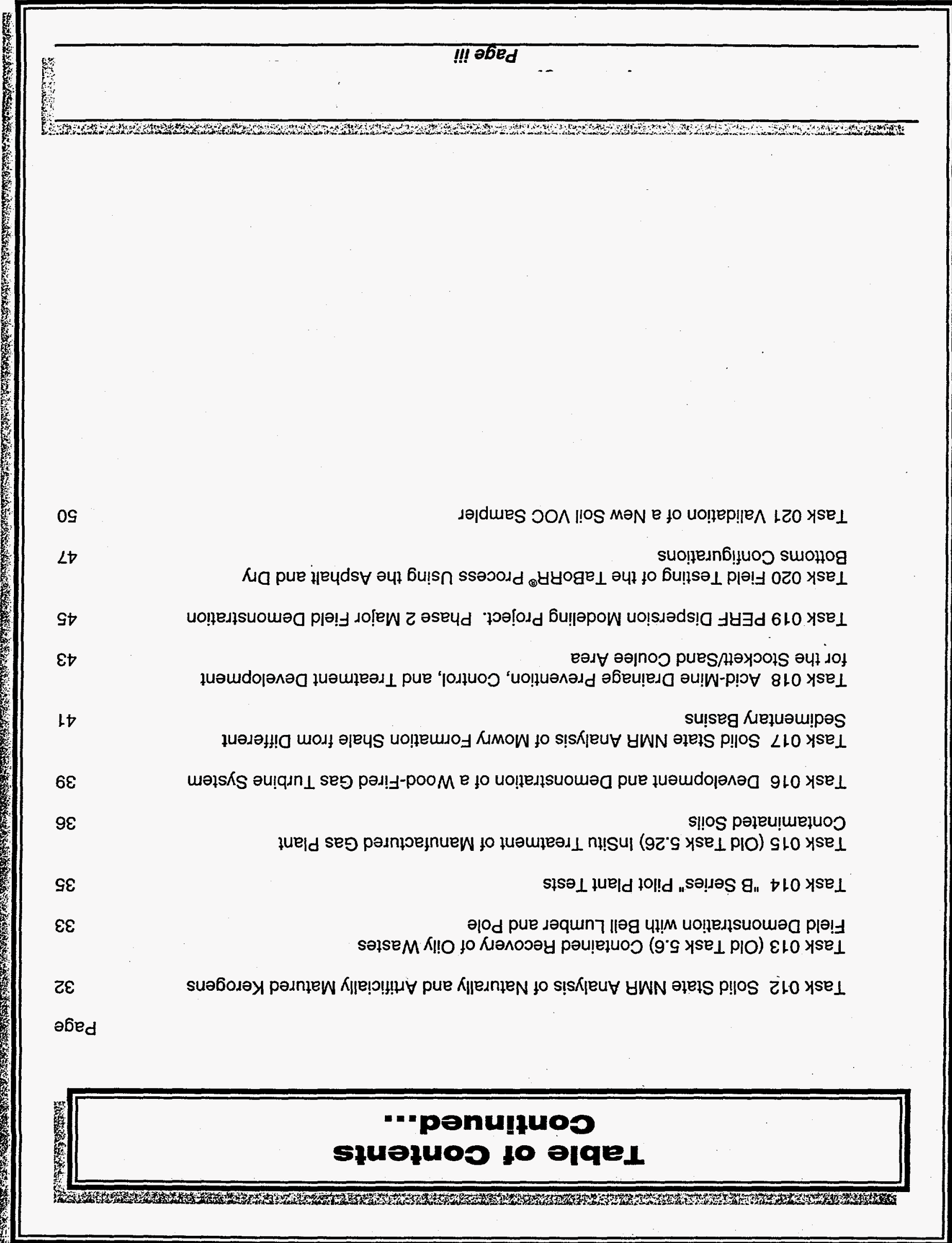




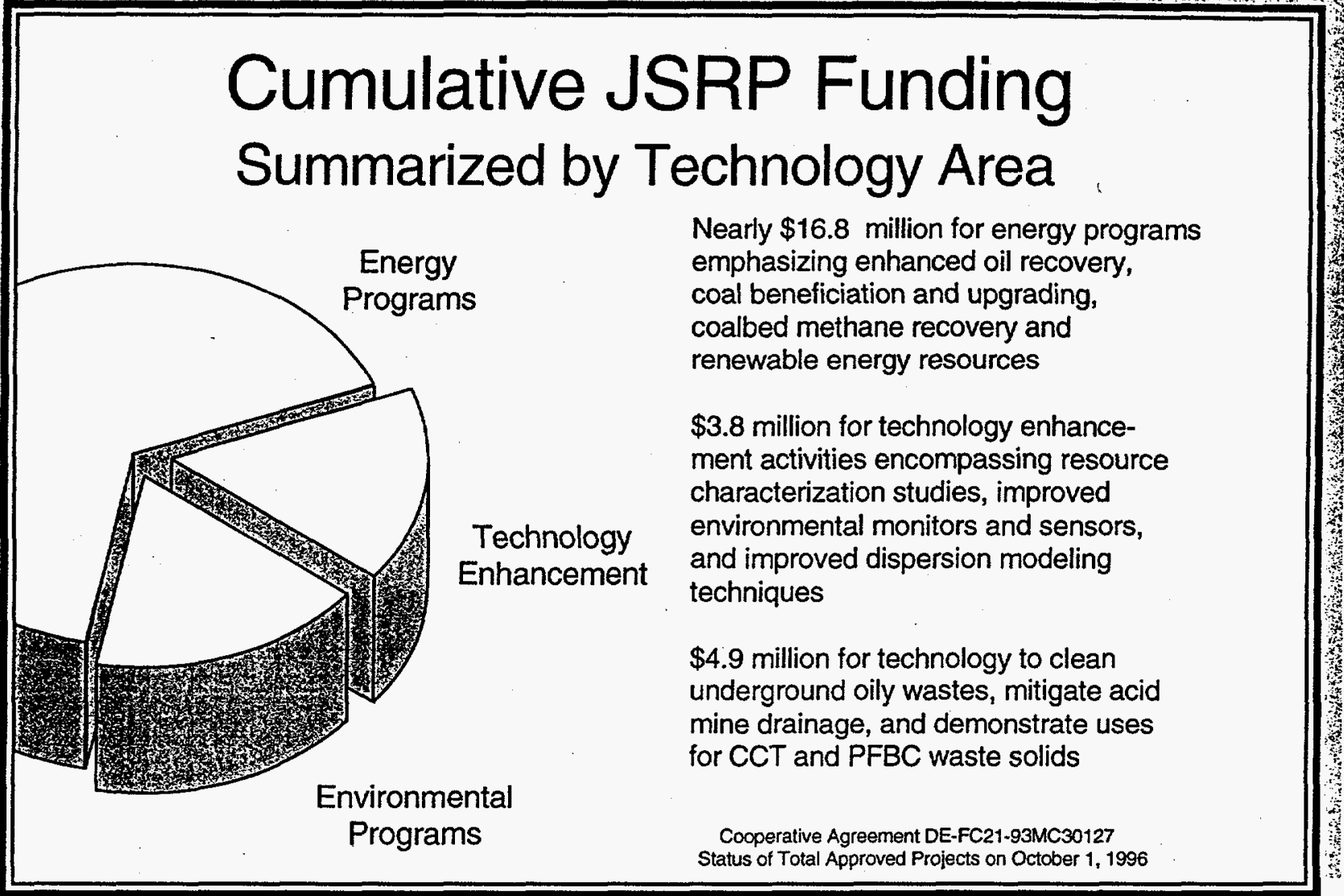

WRI's JSR Program is Focused on Technology Development to Meet National and Regional Needs

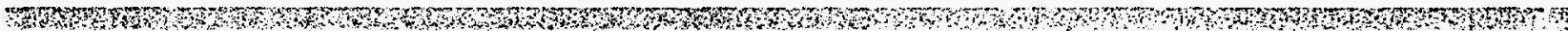
Goals of WRI's Jointly Sponsored Research Program

Increase the production of U.S. and western energy resources: low-sulfur coal, natural gas, oil, and renewable energy resources

Enhance the competitiveness of U.S. and western energy technologies in international markets and assist in technology transfer

Reduce the nation's dependence upon foreign energy supplies and strengthen the U.S. and regional economies

Minimize the impact of energy production and utilization on the environment 


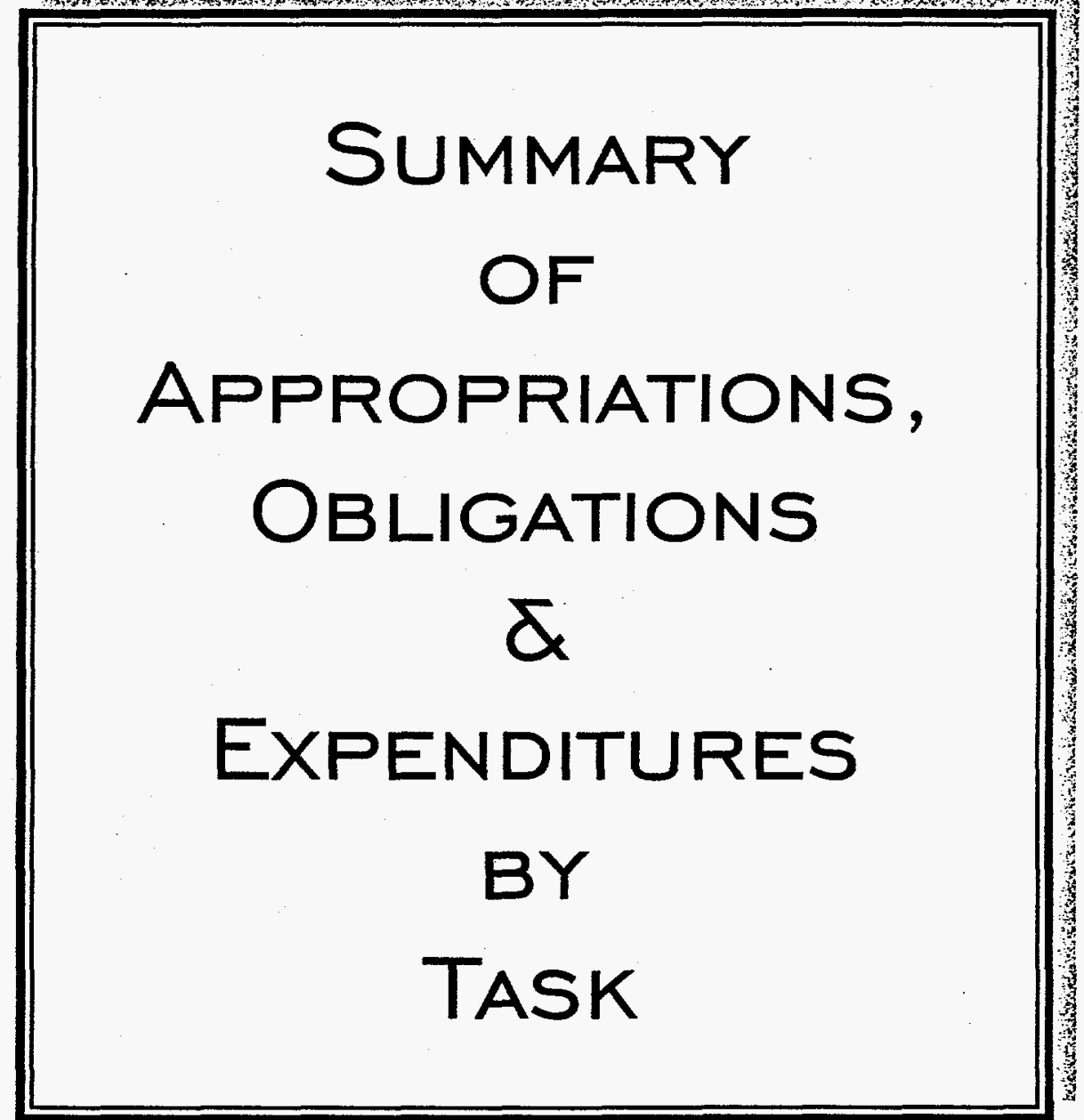




\section{Executive Summary}

\section{Jointly Sponsored Research Program}

The Jointly Sponsored Research Program emphasizes technology commercialization and continues to be highly successful and supported strongly and enthusiastically by WRl's industrial clientele. All of the available Department of Energy (USDOE) funding for each of the first six years has been committed to projects. All available FY 96 funding was obligated in April 1996, however, a reduced commitment by one of our sponsors left an additional $\$ 381,000$ to reobligate. Two new tasks, 20 and 21 , were funded with a portion of this money and a Task 22 proposal is being written to obligate the remaining funds. The demand for funds continues to outstrip available monies and an additional $\$ 3$ million per year in USDOE funding could easily be accommodated. As summarized in Table 1, since the program's inception in 1990, $\$ 17,090,000$ in USDOE funds have been obligated and $\$ 17,044,541$ of these have been committed against an industrial match of $\$ 21,690,285$.

\section{Table 1 \\ Summary of JSRP Funding for FY 1990-96}

\begin{tabular}{|c|c|c|c|c|}
\hline $\begin{array}{l}\text { Fiscal } \\
\text { Year }\end{array}$ & $\begin{array}{l}\text { Funds } \\
\text { Available }\end{array}$ & $\begin{array}{c}\text { Funds } \\
\text { Committed }\end{array}$ & $\begin{array}{l}\text { No. of } \\
\text { Projects }\end{array}$ & $\begin{array}{l}\text { No. of } \\
\text { New Starts }\end{array}$ \\
\hline 1996 & $2,220,000$ & $2,174,541$ & 20 & $2 n$ \\
\hline 1995 & $2,800,000$ & $2,800,000$ & 18 & 1 \\
\hline 1994 & $2,411,000$ & $2,411,000$ & 17 & 3 \\
\hline 1993 & $2,437,000$ & $2,437,000$ & 14 & 9 \\
\hline 1992 & $2,442,000$ & $2,442,000$ & 17 & 10 \\
\hline 1991 & $2,489,000$ & $2,489,000$ & 11 & 5 \\
\hline 1990 & $2,291,000$ & $2,291,000$ & 14 & 14 \\
\hline
\end{tabular}

Since entering into a new JSRP cooperative agreement with the Department of Energy on March 26, 1993 (Cooperative Agreement DE-FC21-93MC30127), WRI has put into place projects utilizing a total of $\$ 10,986,264$ in USDOE funds. These funds have been matched against $\$ 14,586,209$ in industrial funds to produce a program valued at $\$ 25,572,473$. Letters of commitment have already been obtained which envision utilizing more than $\$ 5$ million in FY 97 funds. As a result of this strong demand for program participation, unless additional funding is available, WRI may not be able to work in a significant fashion with any new JSRP participants until FY 98 or beyond. In fact, we estimate that $\$ 6.5$ million would be needed in FY 98 to adequately meet present demand. As Table 1 clearly indicates, new program participants can only be added in those instances where existing money can be reobligated. 


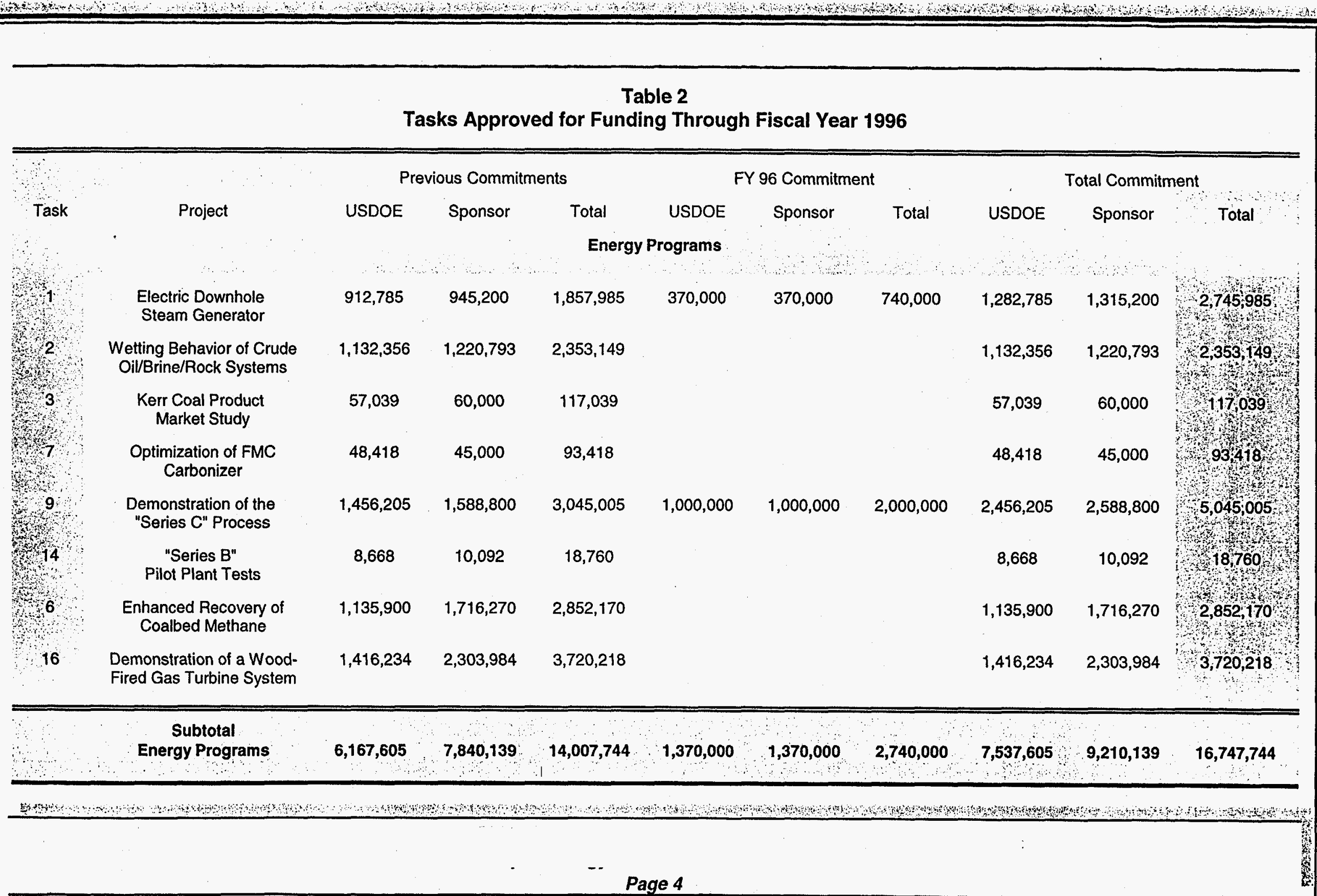




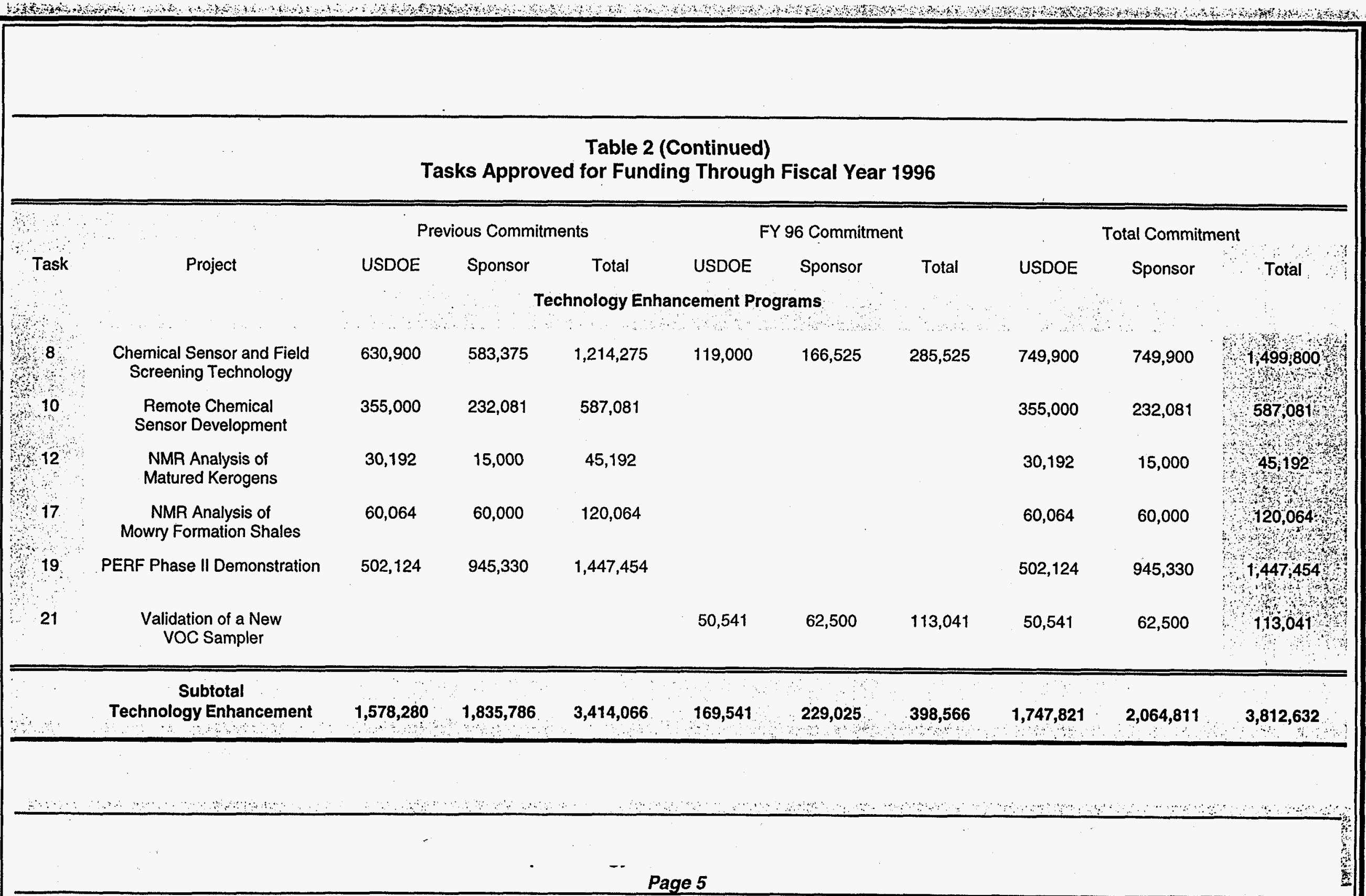




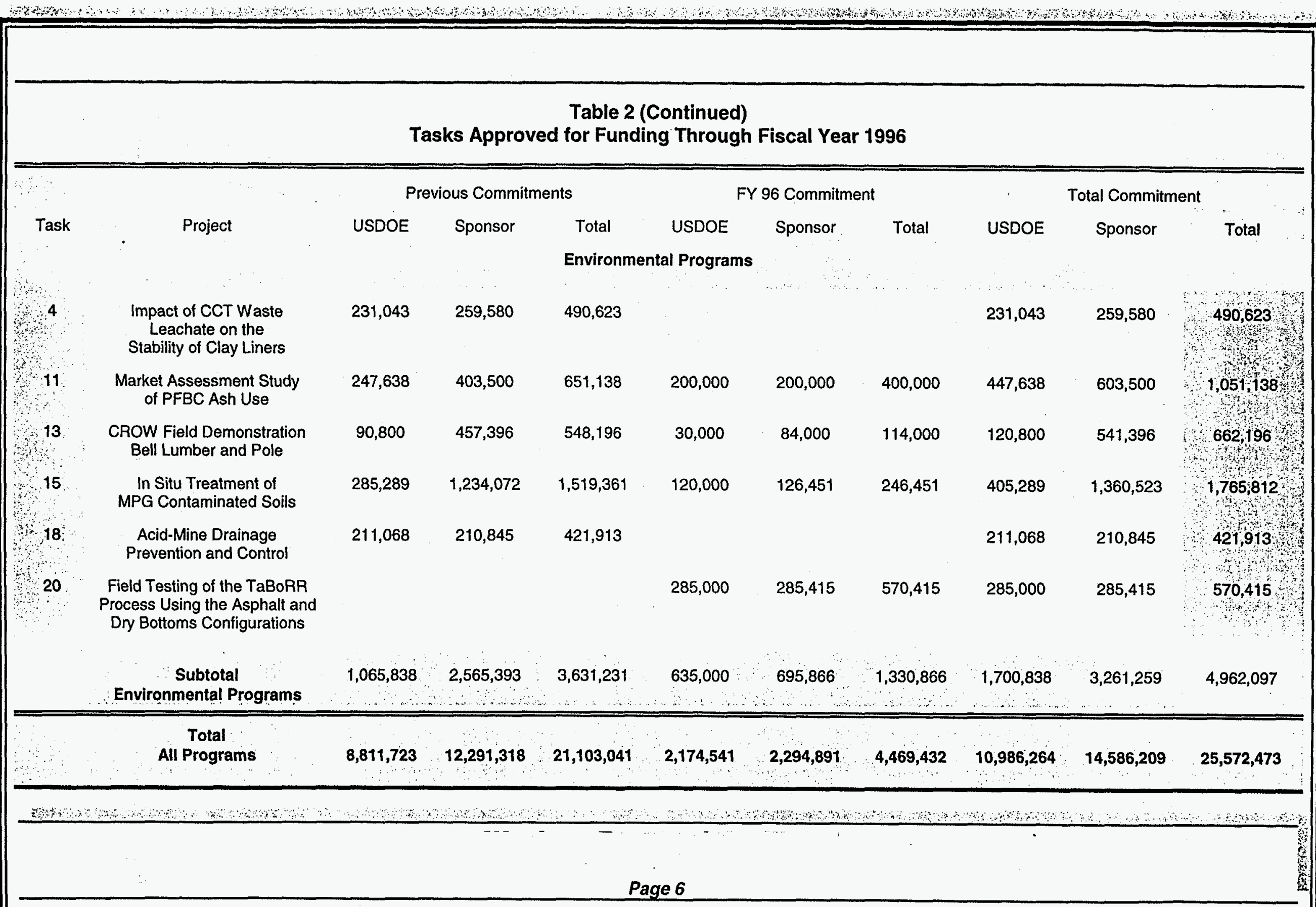




\section{Current Expenditures}

H.

Table 3

Expenditures on Contract DE-FC21-93MC30127

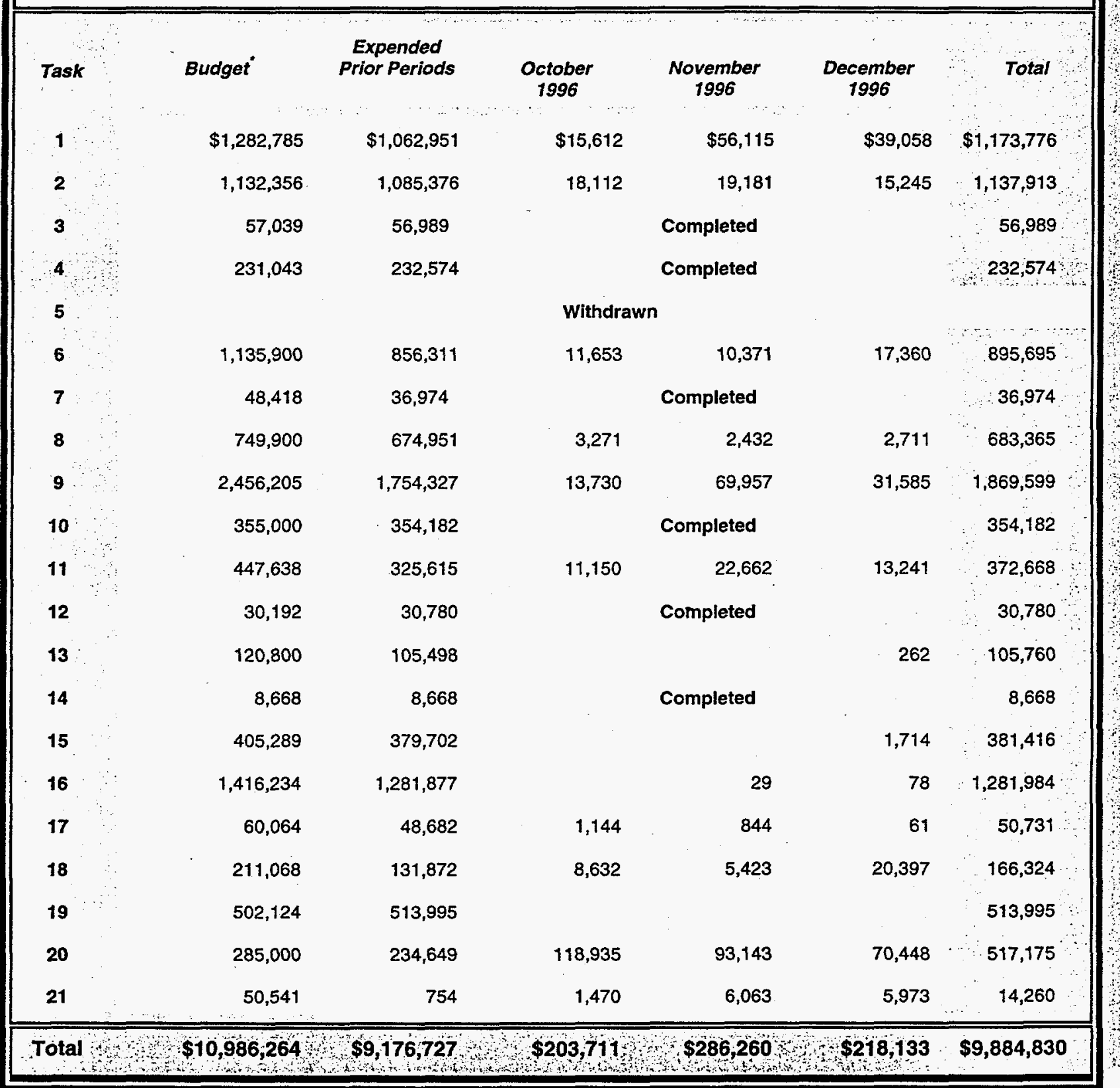

- $\$ 45,459$ remains in unobligated funding. A proposal for this amount is in preparation. 


\section{Technical Highlights}

On Task 001, the primary objective was to run a 72-hour test of the EDSG at rated power. Certain modifications of the current model were required to obviate technical problems reported previously. After a redesign of the feedwater system which incorporated expansion joints within the steam generation chambers, we assembled a 3-chamber model using the PFA tubing.

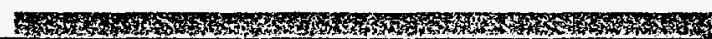

In late November, this EDSG was tested for 85 hours (continuous) at a feedwater flowrate of 4.5 gallons per minute. Power level was maintained near $100 \mathrm{~kW}$ per chamber for the first $\mathbf{8 0}$ hours.

We intend to redesign the EDSG to circumvent the thermal expansion problems associated with the PFA feedwater tubes. After new models are built and tested at the Advanced Technology Center, we will plan a field demonstration in an appropriate test well.

If we are ready to proceed with the field test in February, the previously proposed site at NPR-3 will not be practical because of weather conditions. We are currently negotiating with Chevron to use one of their wells in the Coalinga Field in California for the 72-hour downhole test.

Meetings have been held with independent oil producers in Wyoming (Task 002). Surveys on the effect of brine composition on oil recovery factors have been initiated for the Powder River Basin where very low salinity waterfloods are common practice.

A presentation describing the use of the new soil test kit for detecting fuel contamination in soils at a railroad site, and a presentation describing practical deviations from Henry's law for volatile organic compound analysis were accepted by EPA for a poster session at the EPA Field Screening Symposium in January 1997 (Task 008).
Additionally on Task 008, a new field screening method was developed for determining the presence of fuels containing aromatic components particularly diesel fuel in soils. The EPA Freon extraction/infrared methods estimate fuel concentration by measuring aliphatic $\mathrm{C}-\mathrm{H}$ stretch. Freon is being phased out so alternate methods are needed. Approaches designed to replace these are immunoassay methods and a method involving a Fridel-Crafts alkylation reaction, which both measure the aromatic component of fuel mixtures indirectly with visible color development. The new method measures the aromatic components directly with absorption at $254 \mathrm{~nm}$ with a laboratory spectrophotometer or a fieldportable photometer. The new method is very simple since it does not require the use of highly toxic reagents. Prototype field portable UV photometers were designed and built as part of the JSR program since these are not commercially available.

The method was carried through the American Society for Testing and Materials (ASTM) validation and approval process. It is designated as ASTM Method D-5831-95, Standard Test Method for Screening Fuels in Soils. This method uses low-toxicity chemicals and can be used to screen organic-rich soils. It is also fast, easy, and inexpensive to perform. The screening method calls for extracting a sample of soil with isopropyl alcohol following treatment with calcium oxide. The resulting extract is filtered and the ultraviolet absorbance of the extract is measured at $254 \mathrm{~nm}$. Depending on the information available concerning the contaminant fuel type and availability of the fuel for calibration, the method can be used to determine the approximate concentration of fuel contamination, an estimated value of fuel contamination, or an indication of the presence or absence of fuel contamination. Fuels containing aromatic compounds such as diesel fuel and gasoline as well as other aromatic-containing hydrocarbons such as motor oil, crude oil, and coal oil can be determined. 
Prototype kits are being used by engineering firms on the east coast with good results. These firms are eager to buy kits when they become available from the corporate sponsor, In-Situ, Inc.

On Task 009, the 500,000 ton per year plant constructed by the Thermo Ecotek-KFx partnership using the Series C Process is being shaken down in preparation for commercial operation. The plant experienced a fire on December 24 when heat transfer fluid leaking from the system was ignited. The fire resulted in the loss of one of the two fired heaters in the plant and is expected to result in several weeks of lost time from startup activity.

WRI submitted the final manuscript to the international journal Fuel for publication as part of a special issue on ash management (Task 011). The two-part paper summarized the results of the ash use testing of the Foster Wheeler Energia Oy Karhula low-sulfur coal derived circulating PFBC ash and the American Electric Power high-sulfur coal derived bubbling PFBC ash.

The phase-one, full-scale remediation at the Bell Lumber and Pole Site in New Brighton, Minnesota is operating at conditions approximately one-half the projected values (Task 013). Product recovery

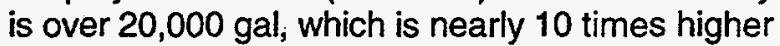
than the projected pump-n-treat volume. A new heat exchanger, on order, to produce the hotinjection water will permit higher injection and production rates.
On Task 015 operation of the Pennsylvania Power and Light's Brodhead Creek Site at Stroudsburg, Pennsylvania was terminated in early June 1996 when EPA treatment criteria had been met. The project is awaiting official closure approval by the EPA, however, the CROW facilities have been decommissioned. The property owner estimated that the CROW process reduced the cost of remediation of the site by over $\$ 1.3$ million dollars. The final report to DOE on the project is $80 \%$ completed.

On Task 020, the TaBoRR flash and stripper units have been assembled and operated. The stripper has been modified to operate in a continuous rather than a semi-batch mode. This modification should improve both thermal efficiency and throughput. Feedstocks with high-water contents require multiple passes through the flash unit. An alternative might be a single flash followed by decantation. If successful, thermal efficiency is improved signficantly and a wider range of feedstocks can be processed. Both of these variations are presently under evaluation.

At the national ASTM meeting in New Orleans in October the process of developing a new ASTM practice describing the use of a tube sampler (such as the EnCore sampler) was approved and initiated (Task 021). The title of the new practice will be "Standard Practice for Using a Coring Tube for Sampling and Storing Soil Samples for Volatile Organic Analysis". 


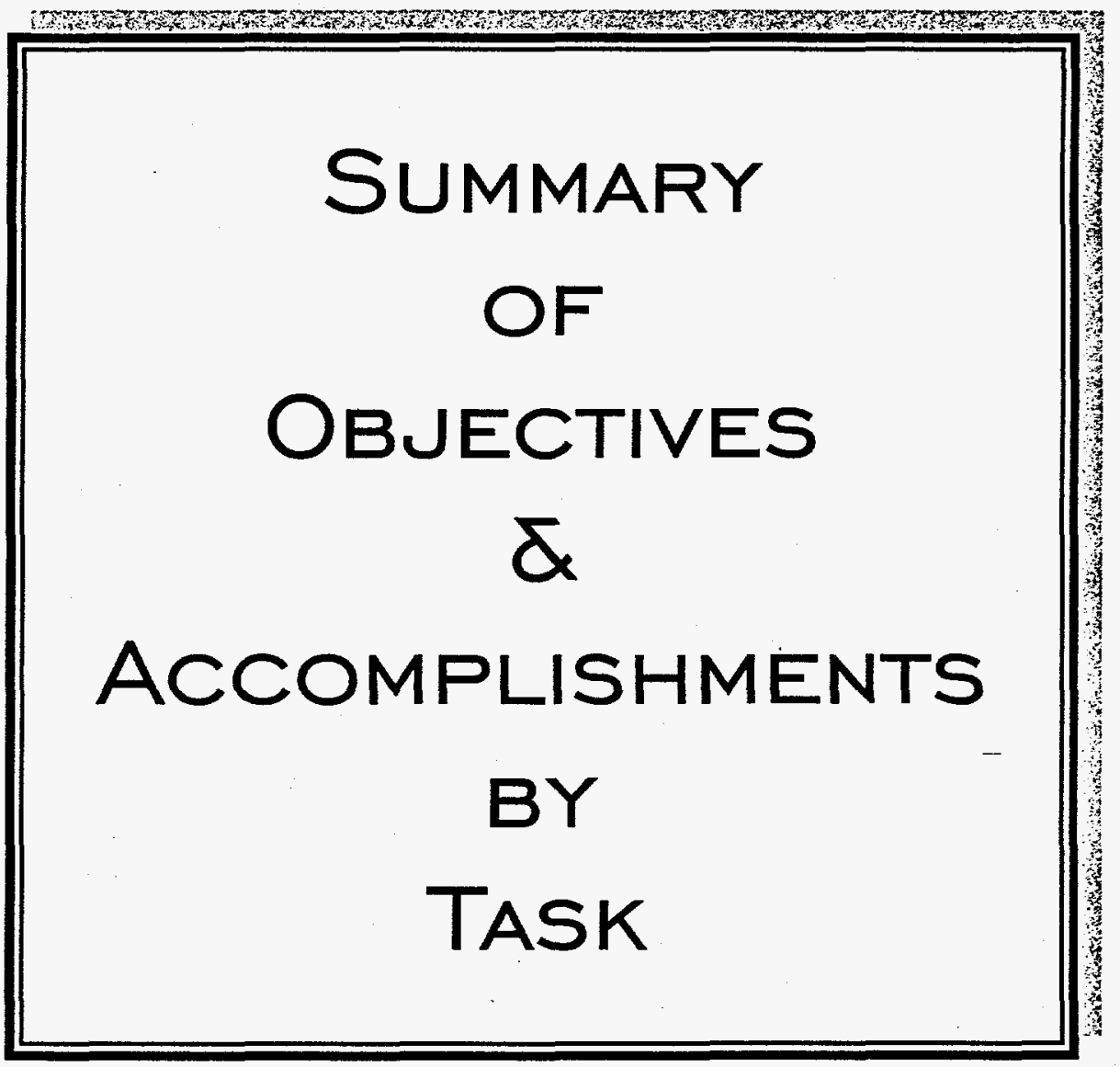




\section{Sponsors}

Meshekow Oil Recovery Consortium, Texaco Incorporated, Occidental International, Chevron Corporation, Pacific Gas and Electric, Camco Products and Services, Fluor Daniel Services, Lawrence Technology, Vesuvius McDanel, Carbon-Carbon Advanced Technologies, University of Wyoming, Pacific Power and Light, and REDA

Reporting Period: October 1 through December 31, 1996

\section{Background}

Conventional oil recovery extracts only 10 to 30 percent of the oil in place in heavy oil reservoirs, leaving a considerable quantity of oil in the ground. Steam stimulation and steam flooding have been shown to increase the amount of oil that can be recovered. Developing a cost-effective technique to generate steam within oil reservoirs will result in improved production and efficiencies.

WRI is developing an electric downhole steam generator for this purpose. The principal steps in this study are to construct and test a three-phase electric powered, low-pressure surface unit, develop and acquire data on three-phase electric, high-pressure downhole devices, and test a multiunit prototype in an oil field.

\section{Task Objectives}

The objective of this task is to design, construct, and demonstrate practical working models of the electric downhole steam generator (EDSG). To be commercially applicable, the EDSG must convert at least one megawatt of power to reasonable quality steam for extended periods without significant maintenance. Using minimally treated produced water as feed, the device must generate steam at formation level with no significant heat losses and be deployable in standard-sized casings.

\section{Quarter Objectives}

The primary objective was to run a 72-hour test of the EDSG at rated power. Certain modifications of the current model were required to obviate technical problems reported previously.

Other objectives for the quarter were:
- Complete a series of tests in the closedloop test apparatus in the University of Wyoming Power Lab, which demonstrated the conditions for the formation a calcium carbonate scale in the EDSG chamber. These results were required by Dennis Tuthill to complete his doctoral dissertation.

- Zhong Shi was scheduled to defend his M. S. Thesis, based on the comparison of his theoretical predictions of EDSG behavior compared to experimental results obtained from the closed-loop test apparatus.

\section{Accomplishments}

The virgin Teflon (PTFE) feedwater tubes were installed in the cast 6-chamber EDSG model in late September, as reported previously. After the imbalance in feedwater supply to the various chamber was corrected, an extended test was 
initiated in early October. After about 10 hours of operation at full power a short circuit occurred through the wall of one of the Teflon feedwater tubes.

After questioning the manufacturer of the tubing, we learned that extruded PTFE is micro-porous because of the process used. The manufacturer recommended that we try PFA Teflon, which is extruded as a melt. We obtained a supply of $0.75^{\prime \prime}$ O. D. by $0.40^{\prime \prime}$ I. D. PFA tubing by mid-November for testing.

Initial results with the PFA feedwater tubes were promising from the standpoint of electrical integrity. This material shows no micro-porosity even after extended exposure to brine and steam at $350^{\circ} \mathrm{F}$. However, it has a coefficient of thermal expansion which is almost twice as large as PTFE. As a result, our longest feedwater tube (which is about 9 feet long) expanded by more than 3 inches in length when the EDSG temperature went from room temperature to $350^{\circ} \mathrm{F}$, the operating conditions at 120 psi test pressure.

After a redesign of the feedwater system which incorporated expansion joints within the steam generation chambers, we assembled a 3-chamber model using the PFA tubing. In late November this EDSG was tested for 85 hours (continuous) at a feedwater flowrate of 4.5 gallons per minute. Power level was maintained at about 100 kilowatts per chamber for the first 80 hours. Over the last 5 hours feedwater salinity was increased to raise the power to 165 kilowatts per chamber as a maximum capacity test. Operation was finally interrupted by a short circuit in one of the chambers.

After disassembling the EDSG, we discovered that considerable iron oxide/hydroxide precipitate had accumulated in all of the chambers. The source of the iron was apparently corrosion of stainless steel components in our circulating system at the ATC test facility. The short circuit apparently was caused by arcing along the surface of the iron precipitate.

Dennis Tuthill completed a series of test runs in the closed-loop test apparatus to quantify the precipitation of calcium carbonate. $\mathrm{He}$ successfully defended his doctoral dissertation in early December. Zhong Shi also completed his M.S. Thesis, which he defended in late November. Both students completed their degree requirements in time to graduate on December 13.

\section{Activities for Next Quarter}

We intend to redesign the EDSG to circumvent the thermal expansion problems associated with the PFA feedwater tubes. After new models are built and tested at the ATC facility, we will plan a field demonstration in an appropriate test well.

If we are ready to proceed with the field test in February, the previously proposed site at NPR-3 will not be practical because of weather conditions. We are currently negotiating with Chevron to use one of their wells in the Coalinga Field in California for the 72-hour downhole test. 
Task
Status Ongoing

\section{Sponsors}

ARCO, British Petroleum, Chevron, Conoco, Dagang (China), ELF (France), Exxon, Marathon, Mobil, NorskHydro (Norway), Phillips, Shell (The Netherlands), Statoil (Norway), and the University of Wyoming

Reporting Period: October 1 through December 31, 1996

\section{Background}

Fluid distribution and the displacement of oil by water or other fluids in an oil reservoir are governed by the fluid-solid interactions (wettability) of that system. Wettability governs interface shapes, which determine the mechanisms and efficiency of oil displacement from reservoir rocks. Because water flooding accounts for more than half of the oil production in the United States, understanding the effect of wettability on oil recovery is of great importance. To this end, WRI has undertaken a study of crude oil/brine/rock interactions for several selected crude oils, including oil from Prudhoe Bay. Special attention is being given to the possibility of increasing the efficiency of waterfloods through selection or adjustment of the composition of the injected brine.

\section{Task Objectives}

- $\quad$ Measure the basic properties of the crude oils selected for wettability control.

- Provide a rationale for selecting core samples with pore geometries that provide definitive tests of scaling laws.

- Improve characterization of wettability by measuring the rate of spontaneous imbibition, and

- Relate wettability to oil recovery by waterflooding.

\section{Quarter Objectives}

- Prepare topical report on recent developments in application of the dynamic Wilhelmy plate to measurement of wettability,.

- $\quad$ Continue program with emphasis on the effect on oil recovery by dilute brines having different types of cations.

\section{Accomplishments}

- $\quad$ Prepared topical report on the effect of alteration of wettability by adsorption of asphaltenes from solution in toluene, and

- Continued experimental program with emphasis on factors that influence the robustness of wettability states induced by crude oil.

\section{Activities for Next Quarter}

- Continue studies of effect of brine composition on oil recovery, and

- Investigate effect of initial water saturation on brine chemistry and oil recovery from chalk.

\section{Objectives for Next Quarter}

- Continue experimental program with emphasis on the effect on oil recovery of brine composition. 


\section{$\angle b \mid 22)_{1}$ srpsieg 337 \\ ejeo pue jue!d!oeg jo ejnłeu6!s}

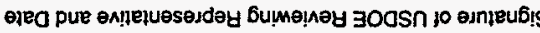

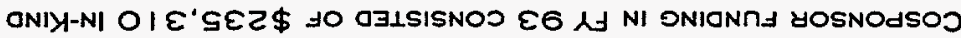

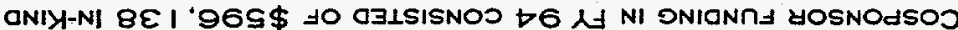

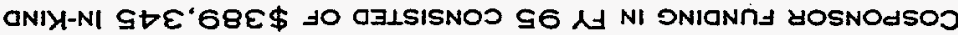
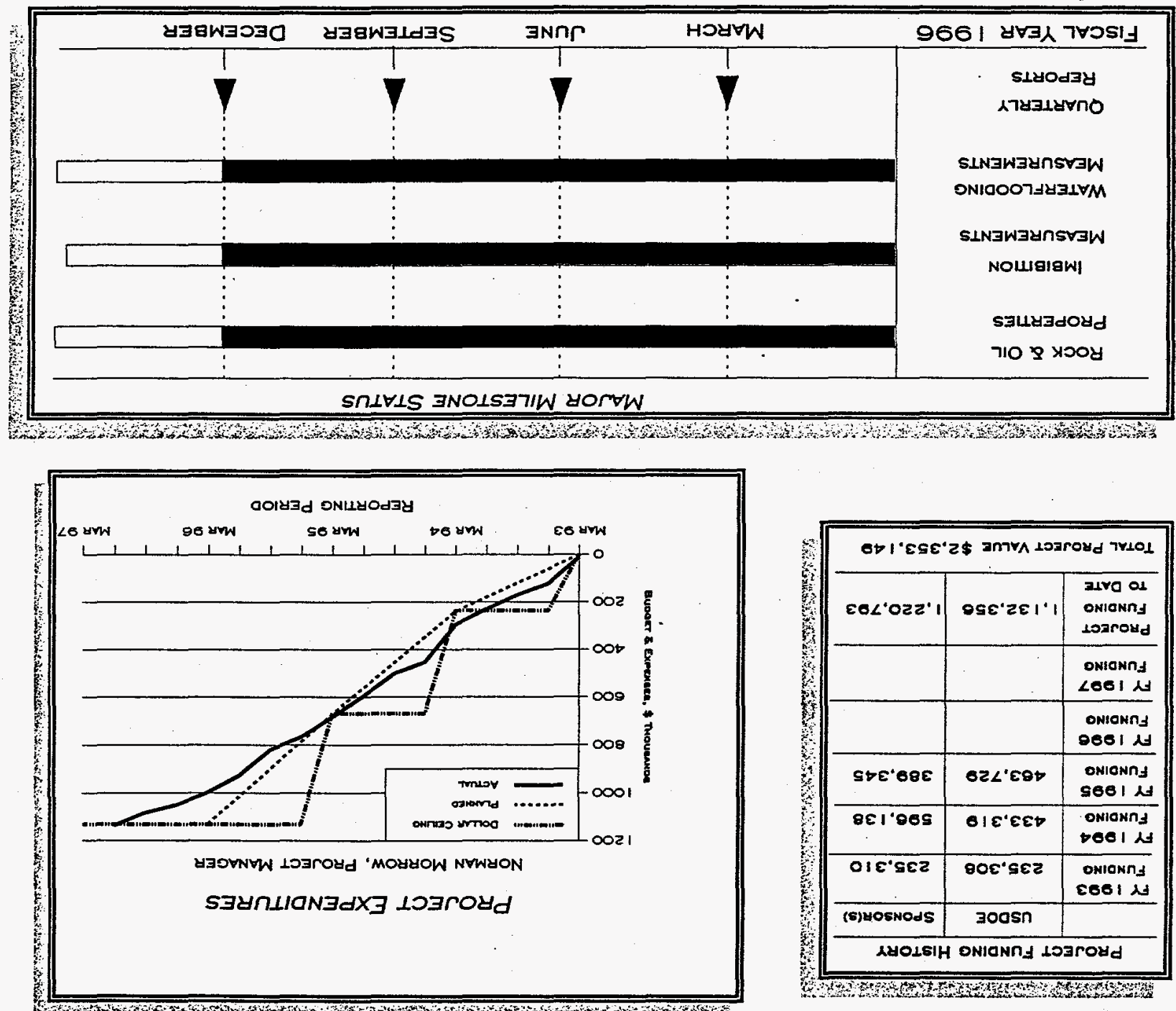

16xis

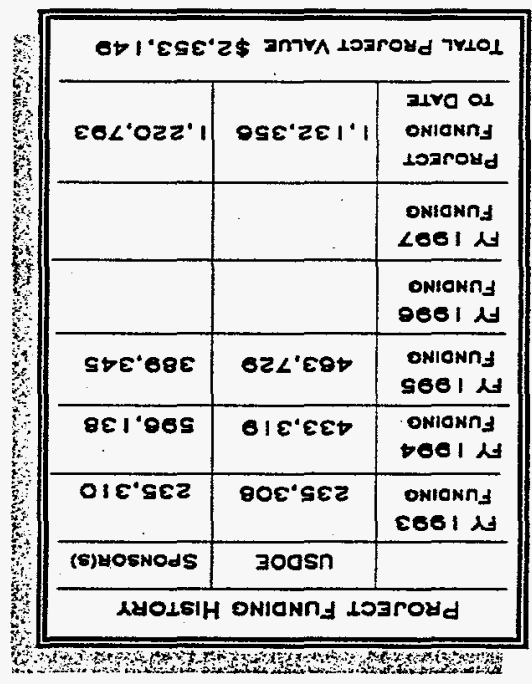

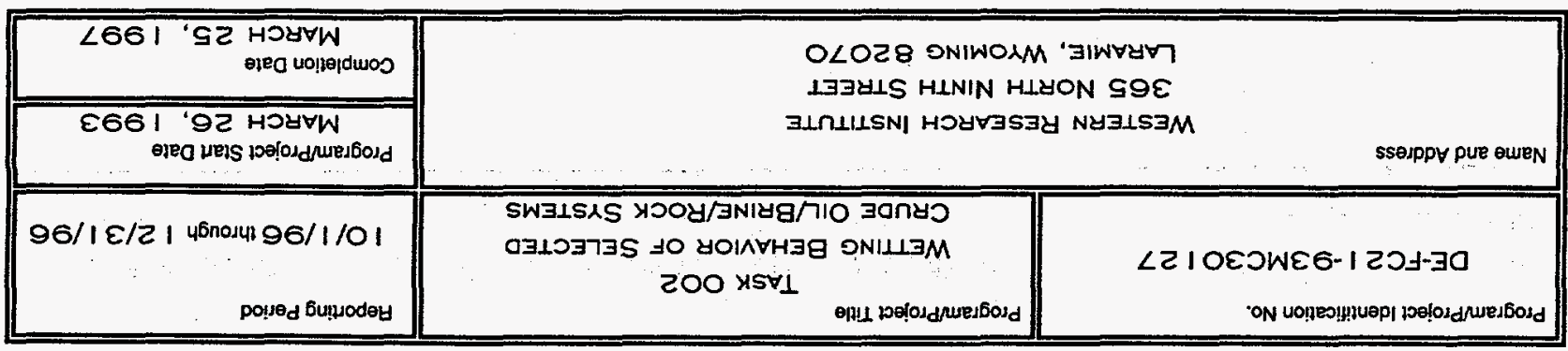




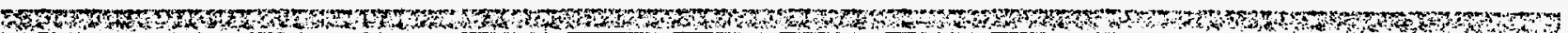

\begin{tabular}{|c|c|c|}
\hline \begin{tabular}{c} 
Task \\
\hline 3
\end{tabular} & $\begin{array}{c}\text { Coal Gasification, Power Generation, } \\
\text { and Product Market Study }\end{array}$ & $\begin{array}{c}\text { Status } \\
\text { Completed }\end{array}$ \\
\hline \multicolumn{1}{c}{$\begin{array}{c}\text { Sponsor } \\
\text { Kerr Coal Company }\end{array}$} \\
\hline \multicolumn{1}{c}{$\begin{array}{c}\text { Reporting Period: October } 1 \text { through December 31, 1996 } \\
\text { need to be evaluated. This study is to perform a market survey of potential products and alternate } \\
\text { technologies that may produce high-value products from coal obtained from the Kerr Company coal } \\
\text { mine in Walden, Colorado. }\end{array}$} \\
Background \\
Status \\
The project has been completed.
\end{tabular}


Task 4
The Impact of Leachate from Clean Coal Technology Waste on the Stability of Clay Liners
Status Ongoing

\section{Sponsor \\ Public Service Company of Colorado}

Reporting Period: October 1 through December 31, 1996

\section{Background}

Wastes generated from clean coal technologies have much different physical and chemical characteristics than the wastes generated from conventional power plants. These wastes can have significantly different impacts on the permeability of a clay liner, which can affect the active lifetime of the liner. This study is evaluating the influence that clean coal technology waste materials will have on the stability of clay liners. Specifically, an understanding of the chemical and physical interactions will be determined between clay liners and waste leachates. The findings of the study will provide industry with valuable information for the management of wastes generated by the implementation of clean coal technology programs.

\section{Task Objective}

The objective of this task is to develop an understanding of the compatibility of clay liner materials and synthetic liners with waste leachates generated from clean coal technologies.

\section{Quarter Objective}

A final project report will be completed and provided to PSC.

\section{Accomplishments}

The hydraulic conductivity evaluations of the clay liner materials have been completed for inclusion in the final report.

\section{Activities for Next Quarter}

A final project report will be completed and provided to PSC and DOE. 


\begin{tabular}{|c|c|c|}
\hline $\begin{array}{l}\text { Program/Project Identification No. } \\
\qquad \text { DE-FC2 } 1-93 M C 30127\end{array}$ & $\begin{array}{l}\text { ProgramProject Title } \\
\text { TASK OO } 4 \\
\text { THE IMPACT OF LEACHATE FROM CLEAN } \\
\text { COAL TECHNOLOGY WASTE ON THE } \\
\text { STABILITY OF CLAY LINERS }\end{array}$ & $\begin{array}{l}\text { Reporting Period } \\
10 / 1 / 96 \text { through } 12 / 31 / 96\end{array}$ \\
\hline \multirow{2}{*}{\multicolumn{2}{|c|}{$\begin{array}{l}\text { IEARCH INSTITUTE } \\
\text { NINTH STREET } \\
\text { IOMING } 82070\end{array}$}} & $\begin{array}{l}\text { Program/Project Start Date } \\
\text { MARCH } 26,1993\end{array}$ \\
\hline & & $\begin{array}{l}\text { Completion Date } \\
\text { MARCH 25, } 1997\end{array}$ \\
\hline
\end{tabular}

\begin{tabular}{|c|c|c|}
\hline \multicolumn{3}{|c|}{ PROJECT FUNDINO HISTORY } \\
\hline & USDOE & SPONSOR(s) \\
\hline $\begin{array}{l}\text { FY } 1003 \\
\text { FUNDINO }\end{array}$ & 123,388 & 136.880 \\
\hline $\begin{array}{l}\text { FY } 1004 \\
\text { FUмото }\end{array}$ & 107,655 & 122,700 \\
\hline $\begin{array}{l}\text { FY } 1005 \\
\text { FUNDINO }\end{array}$ & & \\
\hline $\begin{array}{l}F Y 1006 \\
\text { FUNDINO }\end{array}$ & & \\
\hline $\begin{array}{l}\text { FY } 1907 \\
\text { FUNDINO }\end{array}$ & & \\
\hline $\begin{array}{l}\text { PROJECT } \\
\text { FUNDINO } \\
\text { TO DATE }\end{array}$ & 231,043 & 250,580 \\
\hline
\end{tabular}
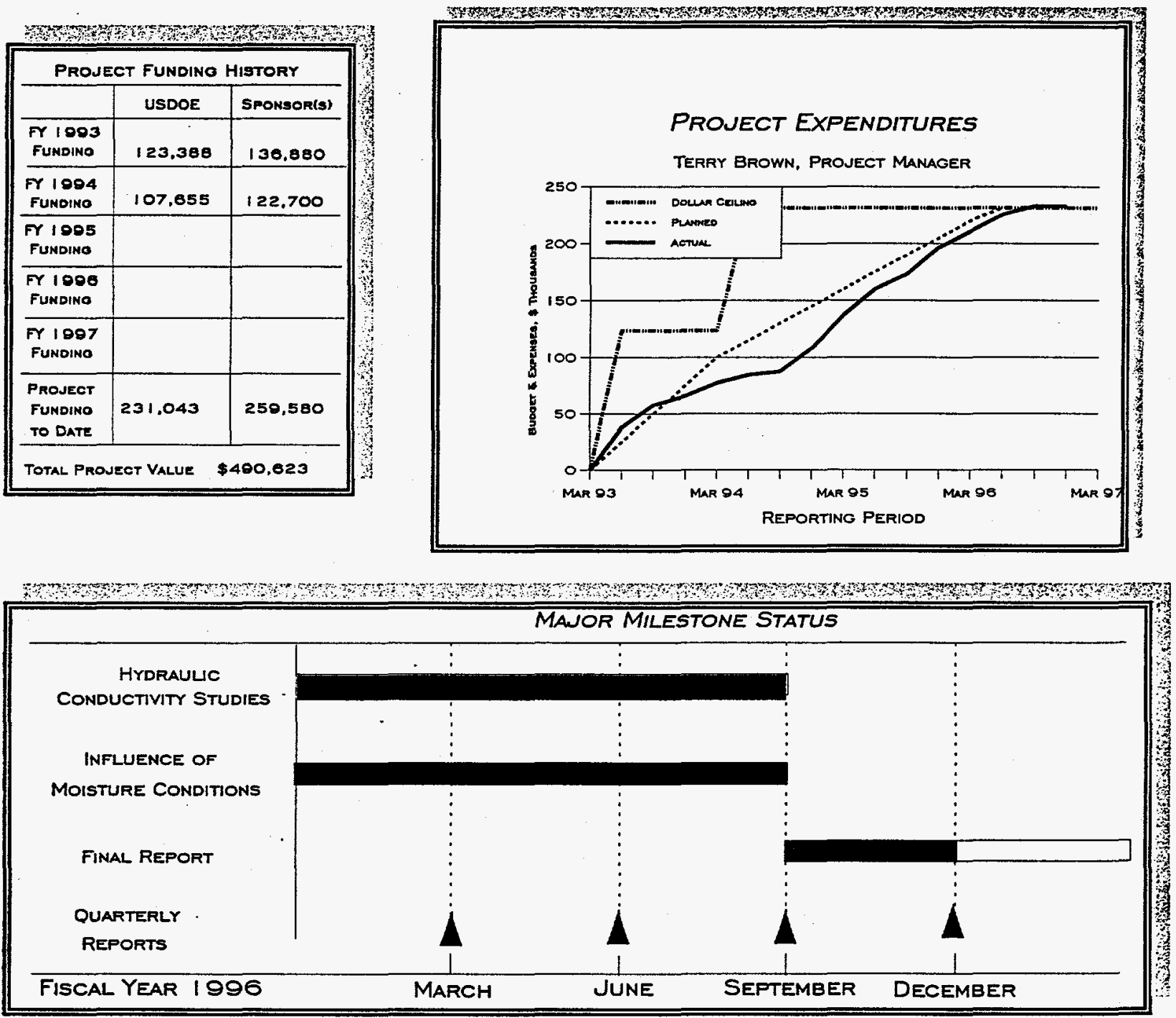

COSPONSOR FUNDING IN FY 94 CONSISTED OF $\$ 122,700 \mathrm{CASH}$

COSPONSOR FUNDING IN FY 93 CONSISTED OF $\$ 1 / 4,880$ CASH AND $\$ 22,000$ IN-KIND

\begin{tabular}{|l|l|l|}
\hline Signature of Recipient and Date & Signature of USDOE Reviewing Representative and Date \\
\hline LE Breder $1 / 27197$ & \\
\hline
\end{tabular}




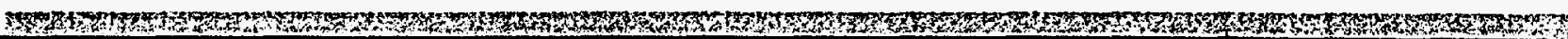

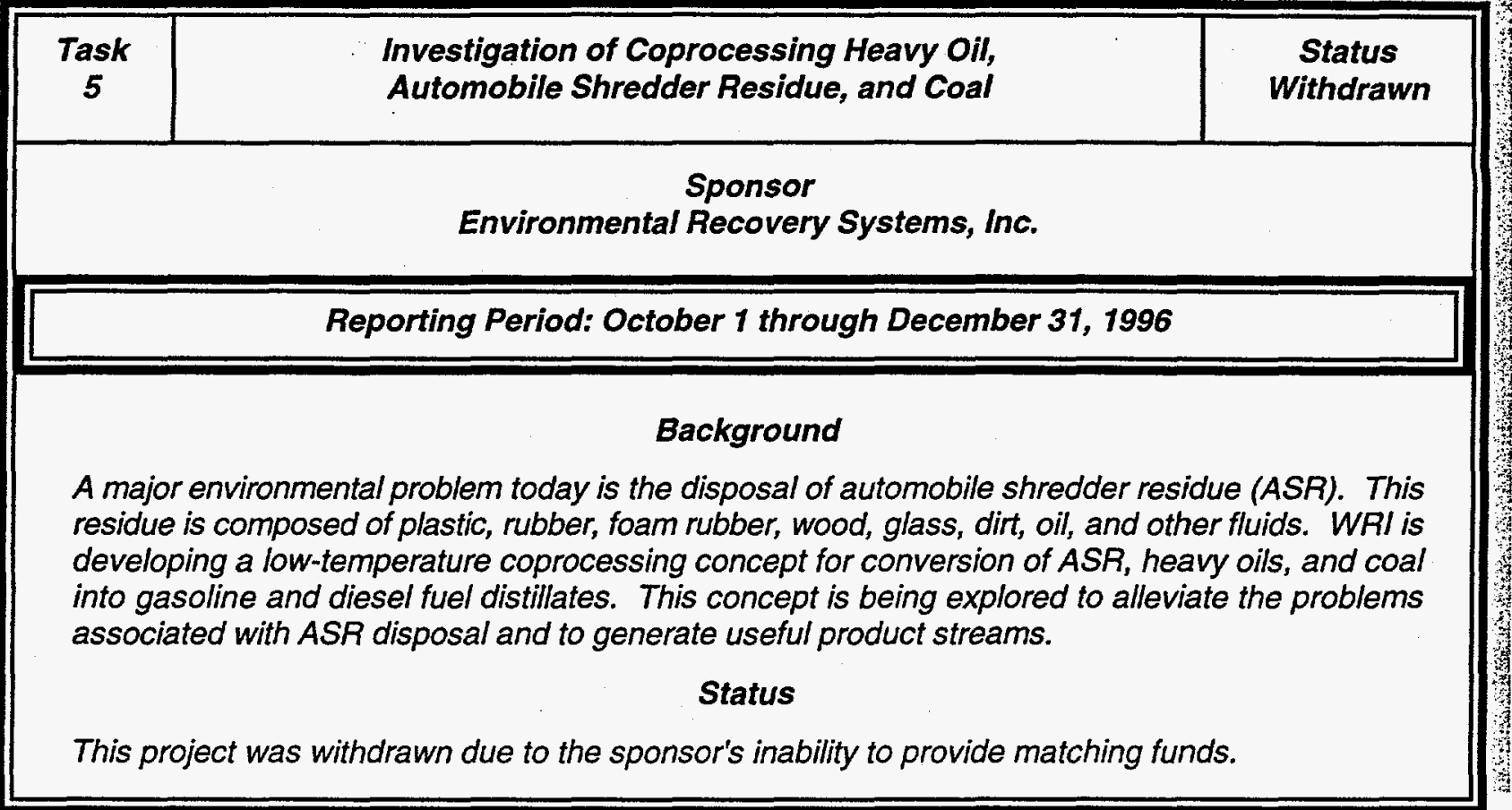




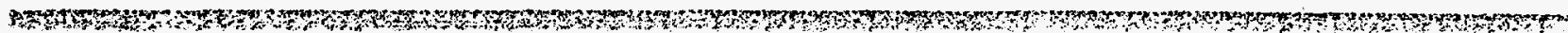

\begin{tabular}{|c|c|c|}
\hline $\begin{array}{l}\text { Task } \\
6\end{array}$ & $\begin{array}{c}\text { Injection into Coal Seams for Simultaneous } \mathrm{CO}_{2} \text { Mitigation } \\
\text { and Enhanced Recovery of Coalbed Methane }\end{array}$ & $\begin{array}{l}\text { Status } \\
\text { Ongoing }\end{array}$ \\
\hline \multicolumn{3}{|c|}{$\begin{array}{l}\text { Sponsors } \\
\text { Amoco, Conoco, Resource Enterprises Inc., and } \\
\text { New Mexico Petroleum Recovery Research Center }\end{array}$} \\
\hline \multicolumn{3}{|c|}{ Reporting Period: October 1 through December 31, 1996} \\
\hline \multicolumn{3}{|c|}{ Background } \\
\hline \multicolumn{3}{|c|}{$\begin{array}{l}\text { This study is evaluating the technical feasibility of injecting } \mathrm{CO}_{2} \text {, a byproduct of methane recovery } \\
\text { from some coalbeds, into the coalbeds as both a technique of mitigating the level of } \mathrm{CO}_{2} \text { emissions } \\
\text { from the production of methane from the coalbeds and as a technique for enhancing the recovery } \\
\text { of methane from the coalbeds. The evaluation will be based on the operation and results of a two- } \\
\text { well field pilot test in northwestern New Mexico. }\end{array}$} \\
\hline
\end{tabular}

\section{Task Objectives}

The overall objective of this task is to test the technical viability of injecting $\mathrm{CO}_{2}$ into the Fruitland Coal to displace methane from the coal and to mitigate $\mathrm{CO}_{2}$ emissions which are a consequence of primary coalbed methane production from surrounding wells in the area. To evaluate this technical viability, a field test was conducted and the test is being interpreted using data measured in WRl's laboratory, as well as using Amoco's state-of-the art coalbed methane simulator. Also, a second pilot of the process is being evaluated using the simulator. Ultimately, the technology developed will be applied to a Wyoming coal. The task is divided into five subtasks:

- Subtask 6.1: Two-Well Pilot Test of $\mathrm{CO}_{2}$ Injection

- $\quad$ Subtask 6.2: $\mathrm{CO}_{2} / \mathrm{N}_{2}$ Laboratory Tests in the Fruitland Coal

- $\quad$ Subtask 6.3: Modeling of Two-Well Pilot Test

- Subtask 6.4: Allison Unit $\mathrm{CO}_{2}$ Pilot Study and

- $\quad$ Subtask 6.5: $\mathrm{CO}_{2} / \mathrm{N}_{2}$ Laboratory Tests in Wyoming Coals.

\section{Quarter Objectives}

- To address any questions raised in the reviews of the three documents submitted to Amoco and to finalize and bind the documents.

- To continue history matching of the Allison Unit and to prepare a draft final document on the study depending upon whether any additional data was provided to WRI by Amoco.

\section{Accomplishments}

Subtask 6.1-Two-Well Pilot Test of $\mathrm{CO}_{2}$ Injection

A draft final report entitled "Two-Well Pilot Test" was reviewed by Amoco and many changes were suggested. The document is still being revised.

Subtask $6.2-\mathrm{CO}_{2} / \mathrm{N}_{2}$ Laboratory Tests in the Fruitland Coal

A draft final report entitled "Development of a Coalbed Methane Adsorption and Displacement System" was reviewed by Amoco. The document has been revised and is essentially complete. 


\section{Subtask 6.3-Modeling of Two-Well Pilot Test}

A draft final report entitled "History Match Studies of the $\mathrm{CO}_{2}$ Pilot Using a Coal Reservoir Description" was reviewed by Amoco. The document has been revised and is essentially complete.

\section{Subtask 6.4-Design of Phase II $\mathrm{CO}_{2}$ Injection}

Some new techiniques for data reduction which were developed during performance of the other subtasks were employed for this subtask. While these techniques were employed in a qualitative way on the other subtasks, quantitative use of the techniques was not attempted. The techniques are being expanded to obtain quantitative information from them for use in the Allison Unit.
Additional data on the pilot were obtained from Amoco and these data are also being interpreted.

Subtask $6.5 \mathrm{CO}_{2} / \mathrm{N}_{2}$ Laboratory Tests in Wyoming Coals

No significant work was accomplished on this subtask.

\section{Activities for Next Quarter}

- $\quad$ Finalize and bind the documents for the first three subtasks.

- $\quad$ History matching of the Allison Unit will be completed and a draft final document will be prepared. 


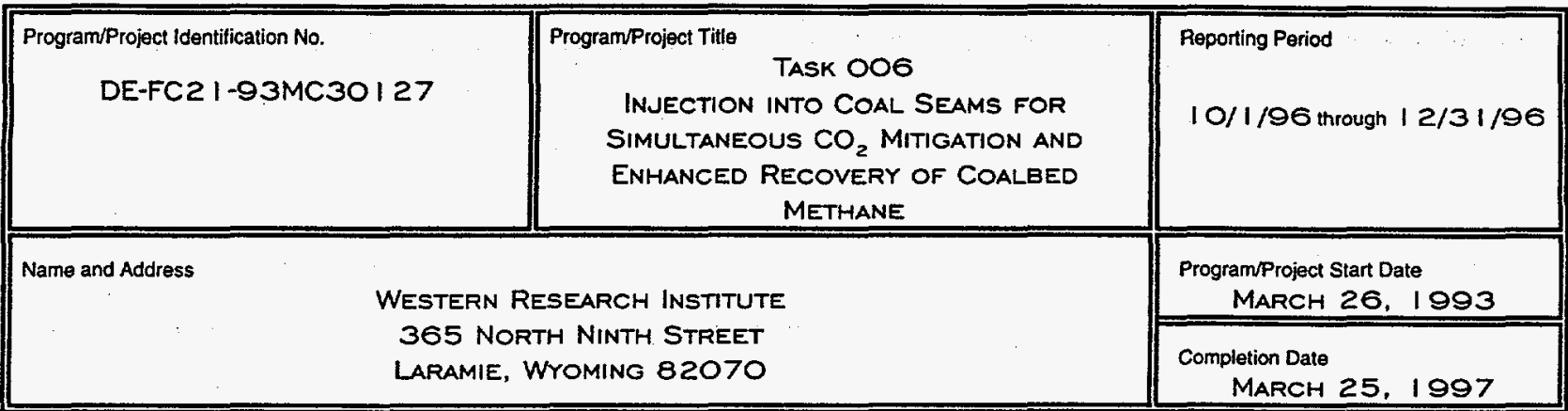

\begin{tabular}{|c|c|c|}
\hline \multicolumn{3}{|c|}{ PROJECT FUNDING HISTORY. } \\
\hline & USDOE & SPONSOR(S) \\
\hline $\begin{array}{l}\text { FY } 1003 \\
\text { FundiNO }\end{array}$ & 812.830 & 1.701 .780 \\
\hline $\begin{array}{l}\text { FY } 1004 \\
\text { FUNDINO }\end{array}$ & & \\
\hline $\begin{array}{l}\text { FY } 1995 \\
\text { FUNDINO }\end{array}$ & 323.261 & $14,48 \mid$ \\
\hline $\begin{array}{l}\text { FY } 1080 \\
\text { FUNDINO }\end{array}$ & & \\
\hline $\begin{array}{l}\text { FY } 1007 \\
\text { FUNDINO }\end{array}$ & & \\
\hline $\begin{array}{l}\text { PROJECT } \\
\text { FUNOINO } \\
\text { TO DATE }\end{array}$ & $1.135,000$ & 1.716 .270 \\
\hline
\end{tabular}
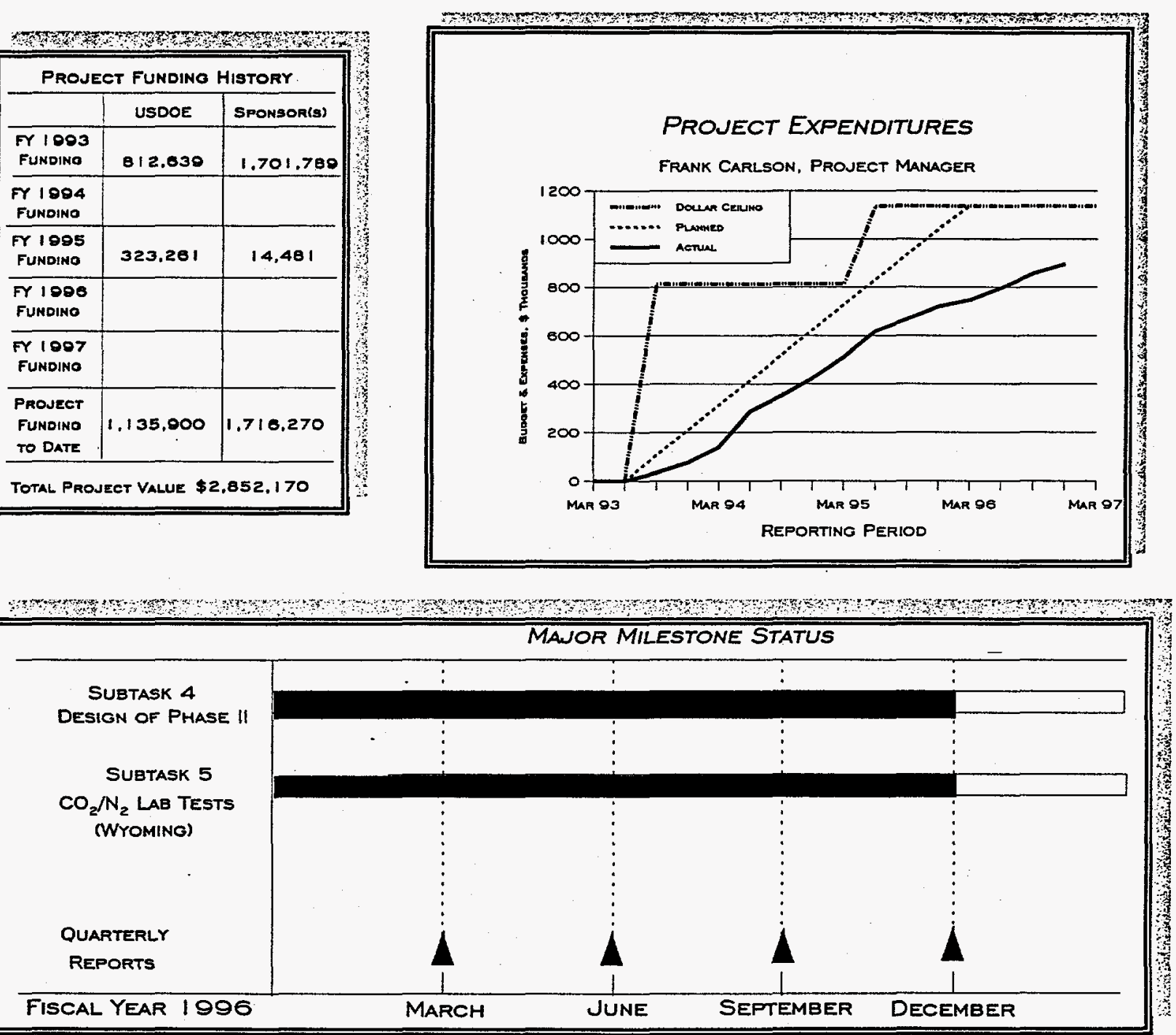

COSPONSOR FUNDING IN FY 95 CONSISTED OF $\$ 14,481 \mathrm{CASH}$

COSPONSOR FUNDING IN FY 93 CONSISTED OF \$41,389 CASH AND \$1,660,400 IN-KIND

\begin{tabular}{|c|c|}
\hline 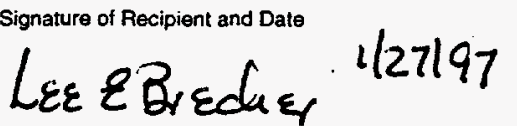 & Signature of USDOE Reviewing Representative and Date \\
\hline
\end{tabular}


PRF

\begin{tabular}{|c|c|c|}
\hline $\begin{array}{c}\text { Task } \\
7\end{array}$ & $\begin{array}{c}\text { Optimization of Carbonizer Operations } \\
\text { in the FMC Coke Process }\end{array}$ & $\begin{array}{c}\text { Status } \\
\text { Completed }\end{array}$ \\
\hline $\begin{array}{c}\text { Sponsor } \\
\text { University of Wyoming Western Coal Consortium }\end{array}$ \\
\hline Reporting Period: October 1 through December 31, 1996 \\
\hline
\end{tabular}

\section{Background}

Operation of the FMC coking process to date has resulted in insufficient production of heavy tar materials that serve as the binder in the coke production. Laboratory tests were conducted by WRI, in conjunction with the University of Wyoming, to develop the optimum operating conditions for the carbonizer to maximize the amount of tar produced for binder and to investigate the applicability of the process to other western coals.

\section{Status}

The project has been completed. 


\begin{tabular}{|c|c|c|}
\hline $\begin{array}{c}\text { Task } \\
8\end{array}$ & $\begin{array}{c}\text { Chemical Sensor and Field Screening } \\
\text { Technology Development }\end{array}$ & $\begin{array}{c}\text { Status } \\
\text { Ongoing }\end{array}$ \\
\hline $\begin{array}{c}\text { Sponsor } \\
\text { In-Situ Incorporated }\end{array}$ \\
\hline Reporting Period: October 1 through December 31, 1996 \\
\hline \multicolumn{1}{|c|}{$\begin{array}{c}\text { Bhe determination or screening of environmental contaminants in the field using portable analytical } \\
\text { methodologies or down-hole real time in-situ measurements is an area of great interest in the } \\
\text { environmental industry. WRI is expanding its efforts into new technology areas for the development } \\
\text { and commercialization of these technologies. }\end{array}$} \\
\hline
\end{tabular}

\section{Task Objectives}

Western Research Institute is expanding its effort with a corporate sponsor, In-Situ Inc. (ISI) to develop additional methodology and prototype devices for down-hole or field applications using various technologies for monitoring chemical species of environmental importance.

\section{Quarter Objectives}

\section{Soil Fuel Test Kit}

- Continue to assist the corporate cosponsor towards the goal of releasing the soil fuel test kit to manufacturing. This will involve assisting in modifications to the photometer.

\section{VOC Probes}

- Continue support work towards down-hole PID probe development.

\section{Other Probes and Sensors}

- Assist the corporate co-sponsor in evaluating commercial OEM sensors for use in chemical monitoring probes.

\section{Accomplishments}

\section{Soil Fuel Test Kit}

- Assistance was provided to the corporate co-sponsor in preparing circuit board layouts for the revised photometer design. The board layouts were completed this quarter.

- The soil test kit patent was issued on October 1,1996 . The patent number is $5,561,065$.

- A soil test kit prototype was sent to Dr. Seth Frisbee at the Johnson Company in Vermont, at his request. He will use it on several projects and is eager to buy final kits when these are available from In-Situ.

Issues related to the soil test kit were addressed at the ASTM meeting in New Orleans in October. Oliver Fordham, EPA Office of Solid Waste asked for copies of the reports describing the method development and validation. These were sent to him. EPA might include the test kit method in the upcoming draft EPA RCRA SW-846 Revision IV method manual in 1997. 
- The abstract for the presentation on the use of the soil test kit at a railroad site at the EPA Field Screening Symposium in January, 1997 was accepted. The manuscript was revised, put into the required format and sent to EPA. A poster session presentation was prepared.

- Reviewers' comments on the manuscript describing validation of the soil test kit method which was submitted to the ASTM Journal for Testing and Evaluation were addressed. A revised manuscript was sent back to the journal. This was accepted for publication in the July, 1997 issue of the journal.

\section{VOC Probes}

- Some additional calibration curves for VOCs in water were obtained for an electrooptical probe and the laboratory sparger.

- The abstract for the presentation of data for Henry's law partitioning of VOCs for the EPA Field Screening Symposium in January, 1997 was accepted. The manuscript was revised, put into the required format and sent to EPA. A poster session presentation was prepared.

\section{Other Probes and Sensors}

- Three prototype $\mathrm{pH}$ and conductivity probes were evaluated at the request of the corporate co-sponsor. Draft final acceptance test (FAT) protocols were developed for these probes.

\section{Activities for Next Quarter}

\section{Soil Fuel Test Kit}

- Continue to assist the corporate cosponsor towards the goal of releasing the soil fuel test kit to manufacturing.

- Make a poster presentation on the use of the soil test kit at a railroad site at the EPA Field Screening Symposium in January.

\section{VOC Probes}

- Continue support work towards down-hole PID probe development.

- Make a poster presentation on practical deviations from Henry's law for VOC analysis at the EPA Field Screening Symposium in January, 1997.

\section{Other Probes and Sensors}

- Assist the corporate co-sponsor in evaluating chemical monitoring probes such as for $\mathrm{pH}$ and conductivity. 


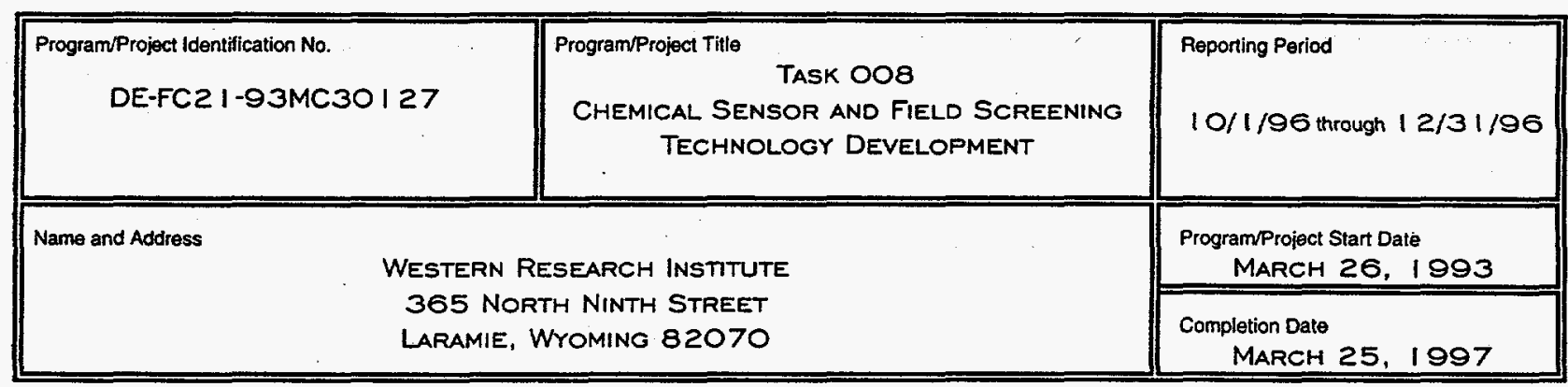

\begin{tabular}{|c|c|c|}
\hline \multicolumn{3}{|c|}{ PROJECT FUNDING HISTORY } \\
\hline & USDOE & SPONSOR(S) \\
\hline $\begin{array}{l}\text { FY } 1003 \\
\text { FUNDINO }\end{array}$ & 100,300 & 217,217 \\
\hline $\begin{array}{l}\text { FY } 1004 \\
\text { FunOINO }\end{array}$ & 186,743 & 151,800 \\
\hline $\begin{array}{l}\text { FY } 1095 \\
\text { FundiNo }\end{array}$ & 247.781 & 214.352 \\
\hline $\begin{array}{l}\text { FY } 1000 \\
\text { FUNDINO }\end{array}$ & 110.000 & 186,525 \\
\hline $\begin{array}{c}F Y 1987 \\
\text { FUNDINO }\end{array}$ & & \\
\hline $\begin{array}{l}\text { PROJECT } \\
\text { FUNDINO } \\
\text { TO DATE }\end{array}$ & 7.40 .000 & 748,000 \\
\hline
\end{tabular}

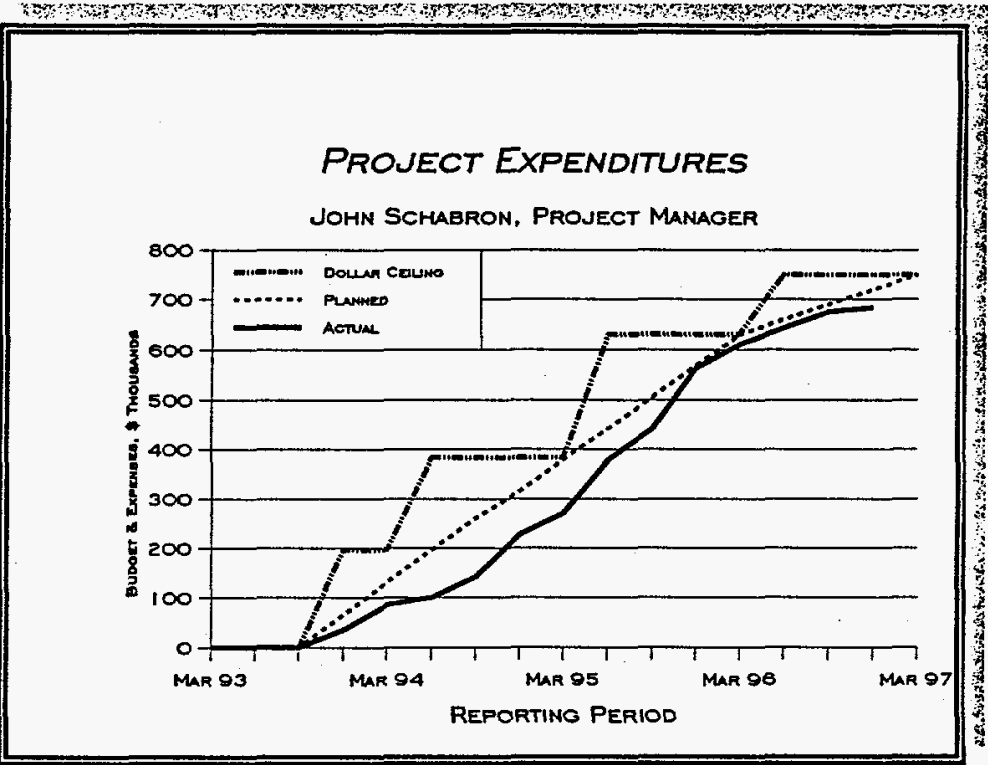

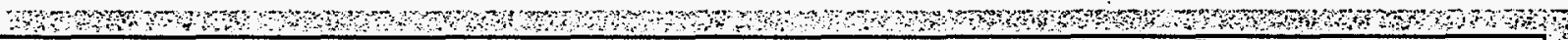

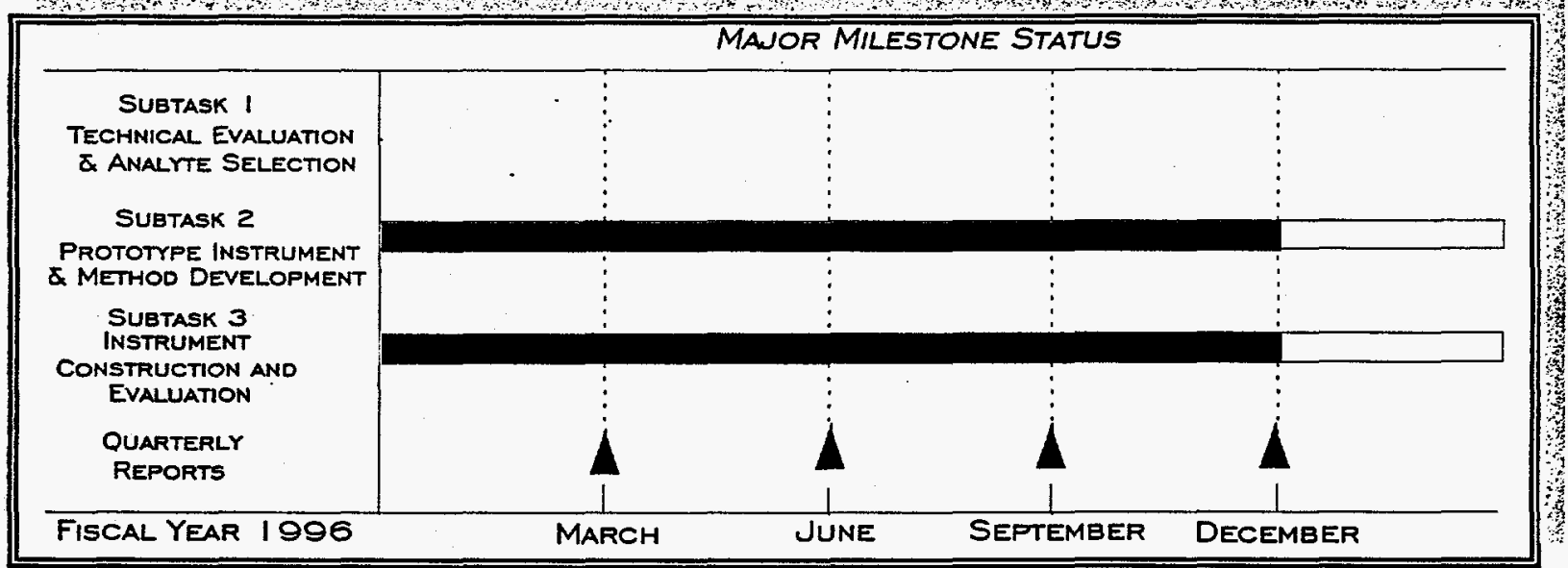

COSPONSOR FUNDING IN FY 96 CONSISTED OF $\$ 73,153$ CASH AND $\$ 93,372$ IN-KIND COSPONSOR FUNDING IN FY 95 CONSISTED OF $\$ 3.709$ CASH AND $\$ 210.643$ IN-KIND COSPONSOR FUNDING IN FY 94 CONSISTED OF \$49,394 CASH AND \$102,4I 2 IN-KIND COSPONSOR FUNDING IN FY 93 CONSISTED OF $\$ 23,744$ CASH AND $\$ 193.473$ IN-KIND

Stonature of Recipient and date




\begin{tabular}{|c|c|c|}
\hline $\begin{array}{c}\text { Task } \\
9\end{array}$ & $\begin{array}{c}\text { Demonstration of the Koppelman "Series C" Process } \\
\text { Using a Batch Test Unit with Powder River Basin Coal as Feed }\end{array}$ & $\begin{array}{c}\text { Status } \\
\text { Ongoing }\end{array}$ \\
\hline $\begin{array}{c}\text { Sponsor } \\
\text { K-Fuel Incorporated }\end{array}$ \\
\hline Reporting Period: October 1 through December 31, 1996 \\
\hline
\end{tabular}

\section{Background}

Although having the desirable characteristic of being low in sulfur, most western coals are comparatively low in heating value. Bench-scale tests have been successfully conducted using the Koppelman "Series C" process in which subbituminous Powder River Basin coal has been converted to a higher value product having the characteristics of a low-sulfur bituminous coal. WRI is working with K-Fuel Inc. to construct and operate a large-scale batch unit that will provide the design basis for a commercial plant and to evaluate the product samples and process emissions from the unit.

\section{Task Objectives}

- (Phase I) Demonstrate the feasibility of the Koppelman Series $C$ process by constructing a $1,000 \mathrm{lb}$. batch test unit; conducting tests to further develop the design basis for a commercial plant; and producing samples of the product for testing and evaluation.

- (Phase II) Improve the process economics by designing, constructing and testing a low-cost, high-efficiency version of the processor.

- Characterize the gaseous and water emissions from the process by determining the quantity and composition of those respective emissions.

- (Phase III) Support the design and operation of the 500,000 ton per year commercial plant now being constructed by KFx and Thermo Ecotek.

- Expand the market for the products by testing high sulfur U.S. coals and foreign coals.

- Increase the product density by developing an extrusion system, and
- $\quad$ Reduce the costs of future plants using the Koppelman Series $C$ process by developing a feed-coal preheater along with an inverted processor.

\section{Quarter Objective}

The objectives for this quarter were to start benchscale testing of foreign coals and to continue support for the commercial plant.

\section{Accomplishments}

This quarter we continued to support KFx and Thermo Ecotek with the startup activities for the commercial plant. We also started bench-scale testing of foreign coal and continued development of the extrusion system.

\section{Activities for Next Quarter}

We will continue to support the startup activities for the KFX-Thermo Ecotek 500,000 ton per day commercial plant. We will also continue benchscale testing of foreign coal and are prepared to conduct pilot plant tests as needed. 


\begin{tabular}{|c|c|c|}
\hline $\begin{array}{l}\text { Program/Project Identification No. } \\
\qquad \text { DE-FC2 } 1-93 \mathrm{MC} 30127\end{array}$ & $\begin{array}{c}\text { ProgramiProject Title } \\
\text { TASK OOO } \\
\text { DEMONSTRATION OF THE KOPPELMAN } \\
\text { "SERIES C" PROCESS USING A BATCH TEST } \\
\text { UNIT WITH POWDER RIVER BASIN COAL } \\
\text { AS FEED }\end{array}$ & $\begin{array}{l}\text { Reporting Period } \\
10 / 1 / 96 \text { through | 2/31/96 }\end{array}$ \\
\hline Name and Address & $\begin{array}{l}\text { ESEARCH INSTITUTE } \\
\text { TH NINTH STREET } \\
\text { VYOMING } 82070\end{array}$ & $\begin{array}{l}\text { Program/Project Start Dale } \\
\text { MARCH 26, 1993 } \\
\begin{array}{c}\text { Completion Date } \\
\text { MARCH } 25,1997\end{array}\end{array}$ \\
\hline
\end{tabular}

\begin{tabular}{|c|c|c|}
\hline \multicolumn{3}{|c|}{ PROJECT FUNDING HISTORY } \\
\hline & USDOE & SPONSOR(S) \\
\hline $\begin{array}{l}\text { FY } 1003 \\
\text { FUNDINO }\end{array}$ & 804.000 & 834,200 \\
\hline $\begin{array}{l}\text { FY } 1004 \\
\text { FUNDINO }\end{array}$ & 051.208 & 054,000 \\
\hline \multicolumn{3}{|l|}{$\begin{array}{l}\text { FY IOOS } \\
\text { FUNDINO }\end{array}$} \\
\hline $\begin{array}{l}\text { FY } 1008 \\
\text { FUNDINO }\end{array}$ & $1,000,000$ & $1,000,000$ \\
\hline \multicolumn{3}{|l|}{$\begin{array}{l}\text { FY } 1007 \\
\text { FUNDINO }\end{array}$} \\
\hline $\begin{array}{l}\text { PROJECT } \\
\text { FUNDINO } \\
\text { TO DATE }\end{array}$ & $\begin{array}{c}2,450,205 \\
-\end{array}$ & $2,588,800$ \\
\hline
\end{tabular}
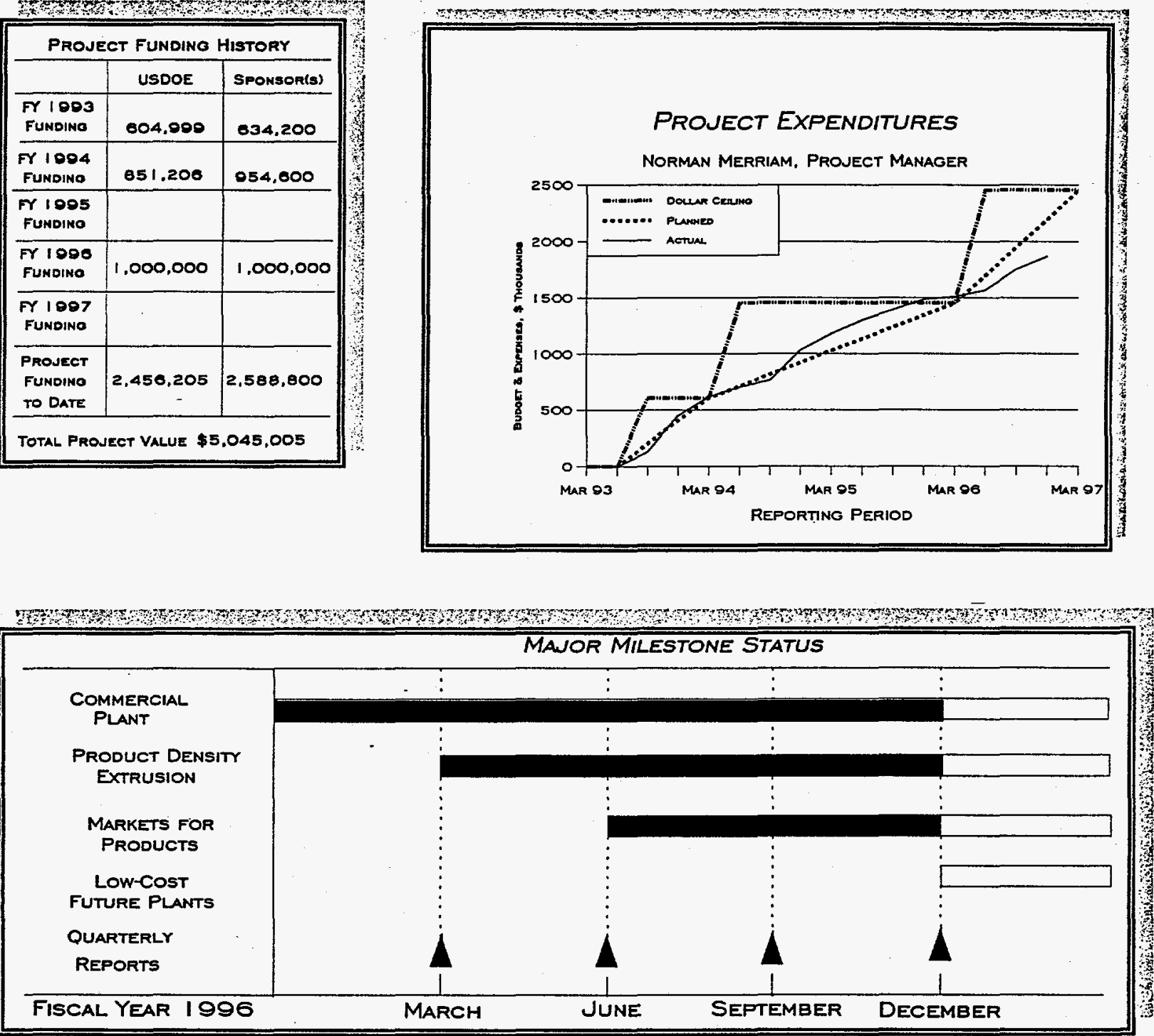

COSPONSOR FUNDING IN FY 96 CONSISTED OF $\$ 250,000$ CASH AND $\$ 750,000$ IN-KIND COSPONSOR FUNDING IN FY 94 CONSISTED OF $\$ 175,000$ CASH AND $\$ 779.600$ IN-KIND COSPONSOR FUNDING IN FY 93 CONSISTED OF $\$ 634,200$ IN-KIND

\begin{tabular}{|ll|l|l|}
\hline Signature of Recipient and Date & Signature of USDOE Reviewing Representative and Date \\
\hline$\varepsilon \varepsilon$ Breduer & $1 / 27 / 97$ & \\
\hline
\end{tabular}




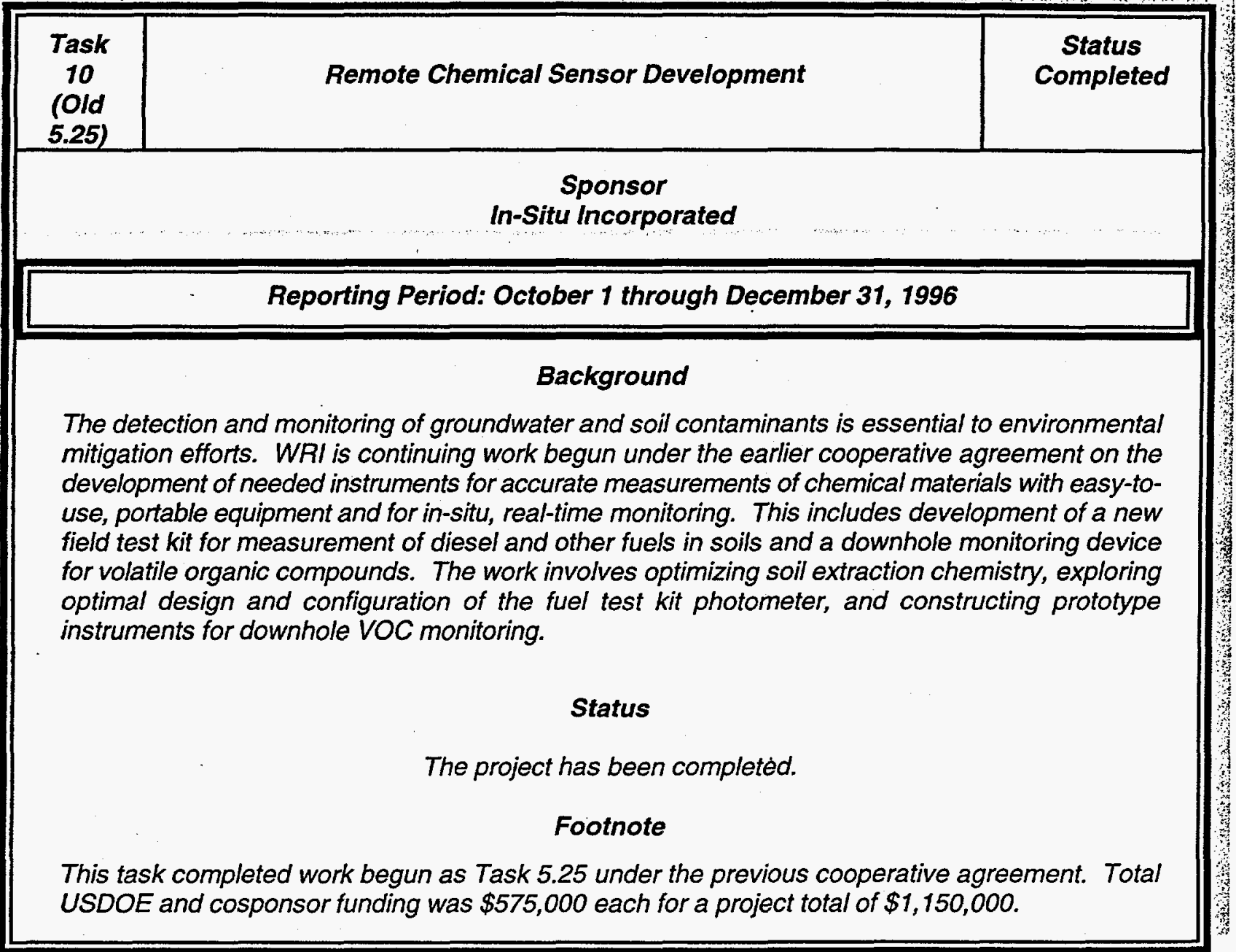


Task

11
Market Assessment and Technical Feasibility

Study of PFBC Ash Use
Status

Ongoing

\section{Sponsor \\ Electric Power Research Institute}

Reporting Period: October 1 through December 31, 1996

\section{Background}

Disposal or use of ash from coal combustion systems are of continuing environmental concern. The chemical characteristics of pressurized fluidized bed combustion (PFBC) ash are quite different from other Clean Coal Technology (CCT) ashes. These characteristics may make the PFBC ash more amenable to options for its use than other CCT ashes. This study is to make a market assessment of potential uses of PFBC ash, evaluate the technical feasibility of these uses, and develop plans for full-scale demonstrations of the most promising options.

\section{Task Objective}

The objective of this task is to determine the market and technical use options for PFBC ash.

\section{Quarter Objectives}

- $\quad$ Finalize manuscripts of papers submitted to the Journal Fuel.

- Continue geotechnical characterization of the ashes as related to the utilization options.

- $\quad$ Continue geotechnical testing as related to structural fill and soil stabilization applications.

- Prepare for synthetic aggregate production testing of the ash blend.

- Initiate soil amendment testing via greenhouse studies.

\section{Accomplishments}

- WRI submitted the final manuscript to the international journal Fuel for publication as part of a special issue on ash management. The paper summarized the results of the ash use testing of the Foster Wheeler Energia Oy Karhula low-sulfur coal derived circulating PFBC ash and the American Electric Power high-sulfur coal derived bubbling PFBC ash.

- Geotechmical testing continued on the ash from pilot circulating PFBC tests at the Foster Wheeler Energia Oy facility in Karhula Finland. Strength and dimensional stability as related to the use of the ash in fill and soil stabilization applications was conducted. Hydration phase analysis composition determination as a function of curing conditions are presently being conducted. Plans for the soil amendment greenhouse study and the synthetic aggregate production testing have been finalized and testing is expected to begin next quarter.

\section{Activities for Next Quarter}

Continue geotechnical testing as related to structural fill and soil stabilization applications.

- Prepare for synthetic aggregate production testing of the ash blend.

- Initiate soil amendment testing via greenhouse studies. 


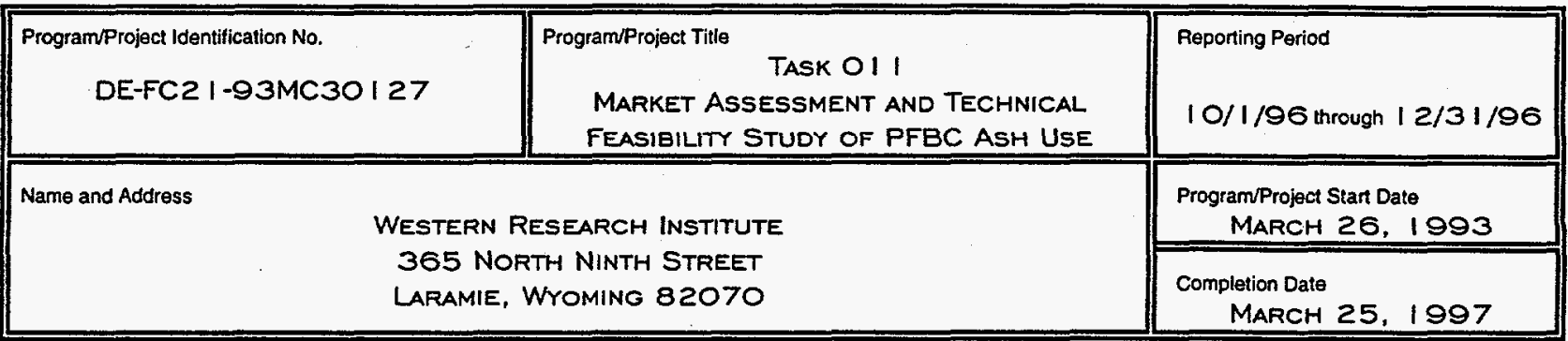

\begin{tabular}{|c|c|c|}
\hline \multicolumn{3}{|c|}{ Project Fundino History } \\
\hline & USDOE & Sponson(s) \\
\hline $\begin{array}{l}\text { FY } 1093 \\
\text { FUNDING }\end{array}$ & 90.098 & 100.000 \\
\hline $\begin{array}{l}\text { FY } 1004 \\
\text { FUNDINO }\end{array}$ & & \\
\hline $\begin{array}{l}\text { FY } 1005 \\
\text { FUNOING }\end{array}$ & 147,640 & 303,500 \\
\hline $\begin{array}{l}\text { FY } 1008 \\
\text { FUNDINO }\end{array}$ & 200,000 & 200,000 \\
\hline $\begin{array}{l}\text { FY } 1997 \\
\text { FUMDINO }\end{array}$ & & \\
\hline $\begin{array}{l}\text { PROJECT } \\
\text { FUMDINO } \\
\text { TO DATE }\end{array}$ & 447,838 & 803,500 \\
\hline
\end{tabular}

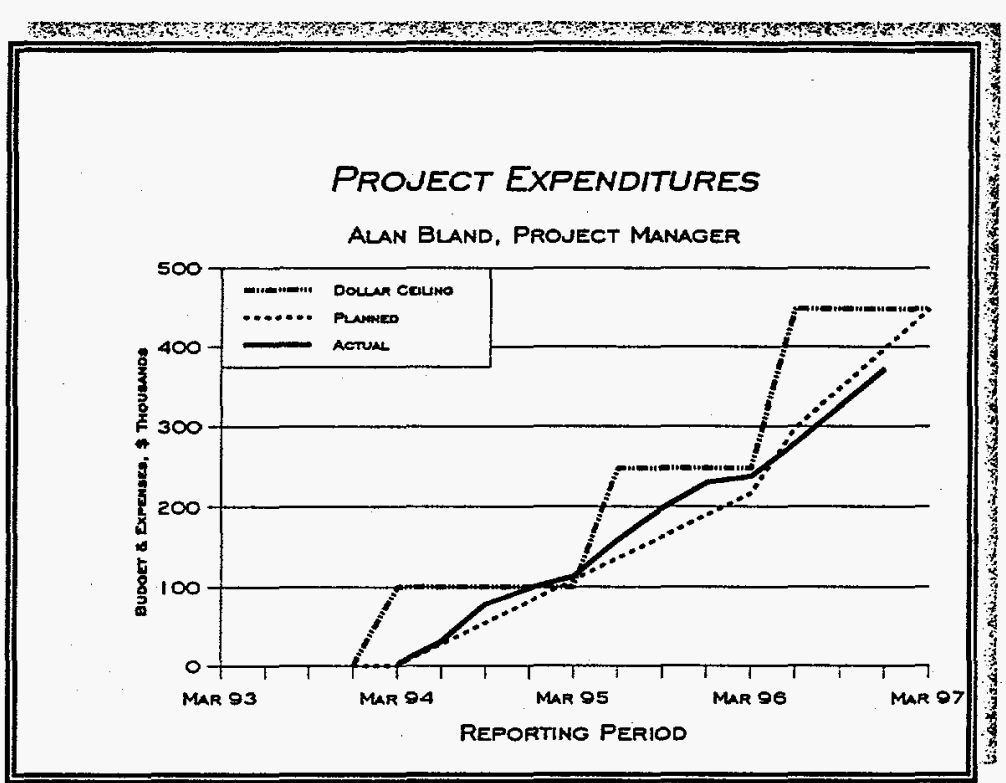

Tof

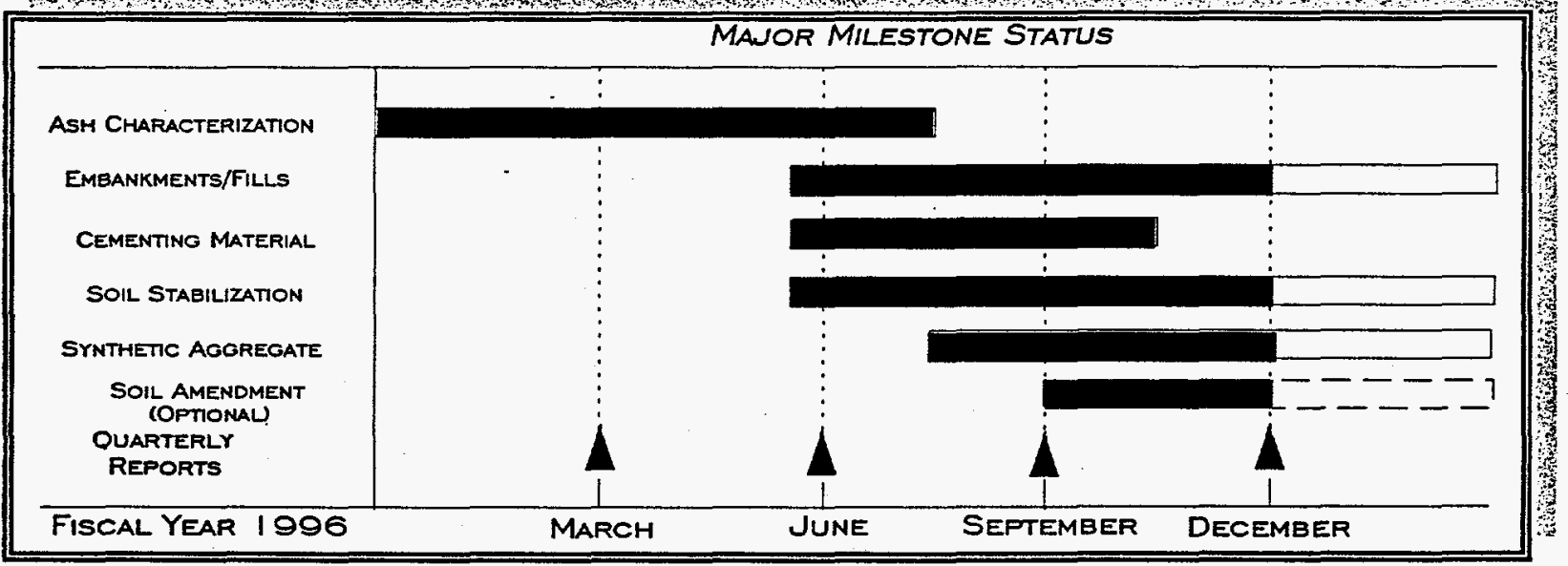

COSPONSOR FUNDING IN FY 96 CONSISTED OF $\$ 200.000$ IN-KIND COSPONSOR FUNDING IN FY 95 CONSISTED OF $\$ 303.500$ IN-KIND COSPONSOR FUNDING IN FY 93 CONSISTED OF $\$ 100,000$ IN-KIND

Signature of Recipient and Date




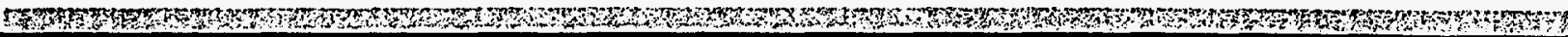

\begin{tabular}{|c|c|c|}
\hline $\begin{array}{c}\text { Task } \\
12\end{array}$ & $\begin{array}{c}\text { Solid State Nuclear Magnetic Resonance (NMR) Analysis } \\
\text { of Naturally and Artificially Matured Kerogens }\end{array}$ & $\begin{array}{c}\text { Status } \\
\text { Completed }\end{array}$ \\
\hline $\begin{array}{c}\text { Sponsor } \\
\text { University of Wyoming--EPSCoR }\end{array}$ \\
\hline \multicolumn{1}{|c|}{ Reporting Period: October 1 through December 31, 1996 } \\
\hline $\begin{array}{l}\text { As part of the University of Wyoming research project to develop new approaches and supporting } \\
\text { technology for oil and gas exploration in the United States, pressure compartmentalization is being } \\
\text { modeled. To do so, fundamental data are required on the natural and artificial maturation of petroleum } \\
\text { source rocks. WRI is performing solid-state NMR measurements to provide a significant part of the } \\
\text { required data. }\end{array}$ \\
Status \\
The project has been completed.
\end{tabular}


Fy

\begin{tabular}{|c|c|c|}
\hline $\begin{array}{c}\text { Task } \\
13 \\
\text { (Old 5.6) }\end{array}$ & $\begin{array}{l}\text { Contained Recovery of Oily Wastes (CROW'TM) } \\
\text { Field Demonstration with Bell Lumber and Pole }\end{array}$ & $\begin{array}{l}\text { Status } \\
\text { Ongoing }\end{array}$ \\
\hline \multicolumn{3}{|c|}{$\begin{array}{l}\text { Sponsor } \\
\text { Bell Lumber and Pole }\end{array}$} \\
\hline \multicolumn{3}{|c|}{ Reporting Period: October 1 through December 31, 1996} \\
\hline \multicolumn{3}{|c|}{ Background } \\
\hline \multicolumn{3}{|c|}{$\begin{array}{l}\text { Operation of a pole and tie treatment plant in New Brighton, Minnesota for a number of years } \\
\text { resulted in contamination of soils at the site with organic materials. WRI is using the CROW } \\
\text { process to demonstrate remediation of the site. The process displaces and recovers part of the } \\
\text { contaminating materials. This is followed by in-situ bioremediation of the residual oily substances. }\end{array}$} \\
\hline \multicolumn{3}{|c|}{ Footnote } \\
\hline \multicolumn{3}{|c|}{$\begin{array}{l}\text { This task completes work begun as Task } 5.6 \text { under the previous cooperative agreement. Total } \\
\text { USDOE funding is } \$ 587,644 \text { and total cosponsor funding is } \$ 2,024,955 \text { for a project total of } \\
\$ 2,612,599 \text {. }\end{array}$} \\
\hline
\end{tabular}

\section{Task Objectives}

The objective of this task is to design, construct, and operate a field demonstration of the CROW ${ }^{\mathrm{TM}}$ process technology to treat a site contaminated with organic wastes from the wood treatment process.

\section{Quarter Objective}

Continue the phase-one, full-scale field demonstration.

\section{Accomplishments}

Continuous extraction began February 26, 1996 and continuous hot-water injection started a week later on March 4, 1996. Injection and extraction rates have averaged 11 and $14 \mathrm{gpm}$ respectively.

The hot-water injection temperature had averaged $180^{\circ} \mathrm{F}$, however, the hot-water heat exchanger failed on July 14, 1996, temporarily preventing hotwater injection. Until $180^{\circ} \mathrm{F}$ injection is reestablished, $70^{\circ} \mathrm{F}$ water is being injected.

The aquifer temperature at the injectors had averaged $165^{\circ} \mathrm{F}$ prior to heat exchange failure.
Aquifer temperature measurements in early September indicate temperatures in the $100^{\circ} \mathrm{F}$ range still exist in some up-gradient wells but the aquifer temperature is declining.

Approximately 4.3 volumes of water have been injected as of the end of November 1996. To date, over 20,000 gallons of oil have been recovered. The injection-production system was shut down in December to treat a large quantity of emulsion that has formed on one production tank. Bell Lumber and Pole continues to use a portion of the recovered product in their pole treatment operation. During this shut down period, a new heat exchanger to produce the heated injection fluid was identified and ordered.

\section{Activities for Next Quarter}

Operation of the phase-one, full-scale remediation will continue next quarter. Getting the hot-water injection system back on line will receive highest priority. 


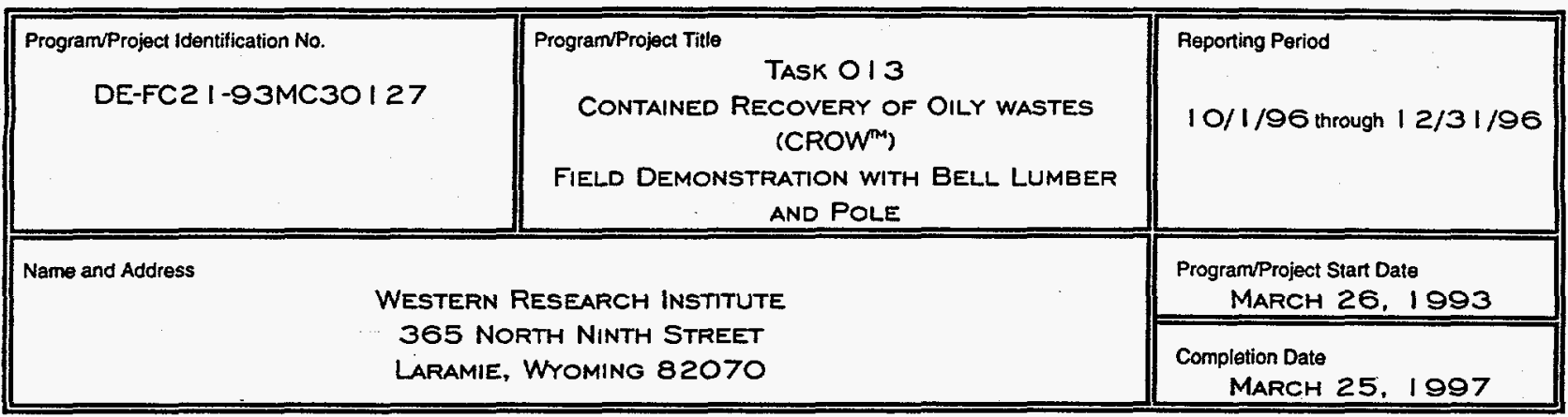

\begin{tabular}{|c|c|c|}
\hline \multicolumn{3}{|c|}{ PROJECT FUNDINO HISTORY } \\
\hline & USDOE & SPONSON(s) \\
\hline $\begin{array}{l}\text { FY } 1003 \\
\text { FuNDINO }\end{array}$ & 00,800 & \\
\hline $\begin{array}{l}\text { FY } 1004 \\
\text { FunDINO }\end{array}$ & & 207.300 \\
\hline $\begin{array}{l}\text { FY } 1005 \\
\text { FunDINO }\end{array}$ & & 250,000 \\
\hline $\begin{array}{l}\text { FY } 1908 \\
\text { FUNDINO }\end{array}$ & 30,000 & 84,000 \\
\hline $\begin{array}{l}\text { FY } 1007 \\
\text { FUNDINO }\end{array}$ & & \\
\hline $\begin{array}{l}\text { PROJECT } \\
\text { FUNDINO } \\
\text { TO DATE }\end{array}$ & 120,800 & 541.396 \\
\hline
\end{tabular}
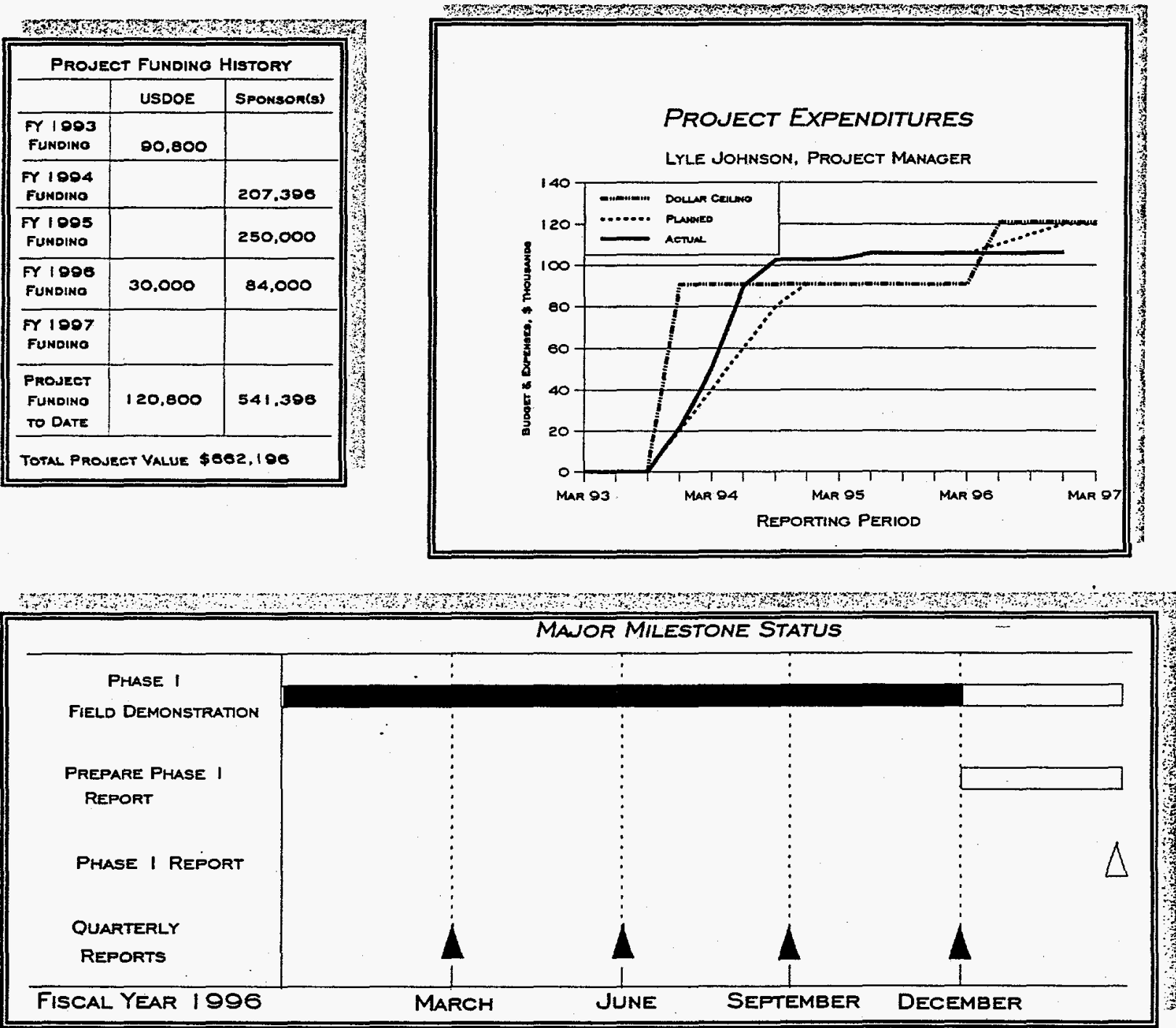

THE PROJECT COSPONSOR HAS ADDED AN ADDITIONAL \$541,396 CASH TO THE PROJECT RAISING THEIR TOTAL CONTRIBUTION FROM \$1,940,955 TO $\$ 2,482,351$

Lignature of Recipient and Date




\begin{tabular}{|c|c|c|}
\hline $\begin{array}{c}\text { Task } \\
14\end{array}$ & $\begin{array}{c}\text { "B Series" } \\
\text { Pilot Plant Tests }\end{array}$ & $\begin{array}{c}\text { Status } \\
\text { Completed }\end{array}$ \\
\hline $\begin{array}{c}\text { Sponsor } \\
\text { Heartland Fuels Corporation }\end{array}$ \\
\hline Reporting Period: October 1 through December 31, 1996 \\
\hline
\end{tabular}

\section{Background}

In a previous JSRP task, WRI participated with Heartland Fuels Corporation in conducting pilotscale tests of the " $B$ " series process using three different coals. The present study determined the characteristics of the process condensate when operated at lower temperatures than previously tested. Seven tests were conducted in the pilot plant and samples of the condensate were collected and analyzed.

\section{Status}

The project has been completed. 


\begin{tabular}{|c|c|c|}
\hline $\begin{array}{l}\text { Task } \\
15 \\
\text { (Old } 5.26)\end{array}$ & $\begin{array}{l}\text { In Situ Treatment } \\
\text { of Manufactured Gas Plant Contaminated Soils } \\
\text { Demonstration Program }\end{array}$ & $\begin{array}{l}\text { Status } \\
\text { Ongoing }\end{array}$ \\
\hline \multicolumn{3}{|c|}{$\begin{array}{c}\text { Sponsors } \\
\text { Pennsylvania Power and Light, US Environmental Protection Agency, Gas Research Institute, } \\
\text { and Electric Power Research Institute }\end{array}$} \\
\hline \multicolumn{3}{|c|}{ Reporting Period: October 1 through December 31, 1996} \\
\hline \multicolumn{3}{|c|}{ Background } \\
\hline \multicolumn{3}{|c|}{$\begin{array}{l}\text { The process of manufacturing gas from coal years ago resulted in the contamination of soils with } \\
\text { carcinogenic materials. One such site that is presently being cleaned is the Brodhead Creek Site } \\
\text { in Stroudsburg, Pennsylvania. WRI is using its CROW process in conjunction with in-situ } \\
\text { biotreatment to demonstrate remediation of the site. The overall steps in the study are to design } \\
\text { the application of the CROW process to the site, obtain permits, construct and operate the field } \\
\text { demonstration test and evaluate the results. }\end{array}$} \\
\hline \multicolumn{3}{|c|}{ Footnote } \\
\hline \multicolumn{3}{|c|}{$\begin{array}{l}\text { This task completes work begun as Task } 5.26 \text { under the previous cooperative agreement. Total } \\
\text { USDOE funding is } \$ 518,689 \text { and total cosponsor funding is } \$ 1,360,523 \text { for a project total of } \\
\$ 1,879,212 \text {. }\end{array}$} \\
\hline
\end{tabular}

\section{Task Objective}

The objective of this project is to demonstrate and evaluate the CROW ${ }^{\mathrm{TM}}$ process and bioremediation to remediate a site contaminated with a dense organic fluid. The goal is to achieve treatment levels in the field that are comparable to prior laboratory results.

\section{Quarter Objective}

Begin preparation of the final report on the field demonstration for DOE. Wait on site closure comments from the EPA.

\section{Accomplishments}

Since initiation of the full-scale testing in midNovember 1994, the system was not operated at full design capacity because of several problems. Problems with the injection wells, leakage to the surface and plugging of the well screens, resulted in insertion grouting around several wells and cement caps placed around others. Injection wells had a jetting tool placed in them to allow periodic cleaning. Other problems included precipitation of iron from the produced water and control of the water heater caused by lower than expected flowrates. The iron problem was addressed by installation of a chemical treatment system of sodium hydroxide, hydrogen peroxide, and flocculent for controlled precipitation of the iron in the production tanks and installation of bag filters before the heater and water treatment units to prevent iron entry into these areas. Because of the lower than expected flowrates, control of the hot-water heater was ineffective. To address this problem, a portion of the heater was changed from an on/off control system to a proportional control system. An additional portion of the heater was modified later because higher temperatures were desired.

Continuous operation of the system begin in midJuly, 1995. Approximately 9.5 million gallons of water were injected and 11.6 million gallons of water produced. During the later part of the project, two of the larger monitor wells were 


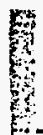

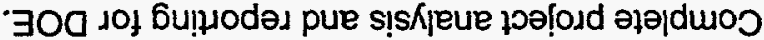

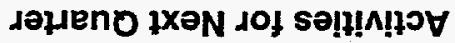

¿66L jo dəuسns ә47

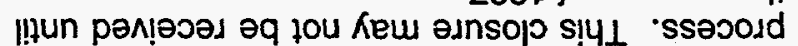

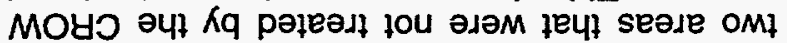

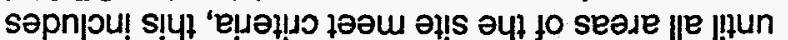

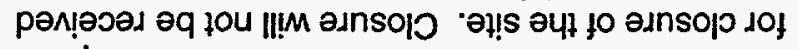

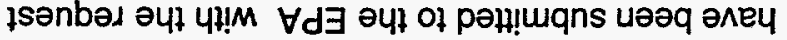

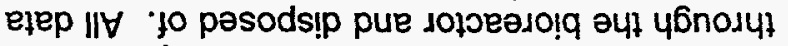

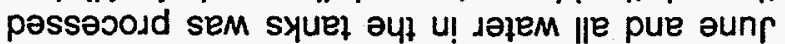
Кㅆeə u! pepuədsns sem uo!̣onpodd pue uo!̣oəlu!

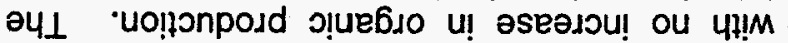

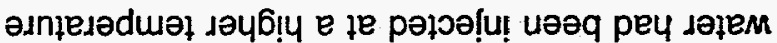

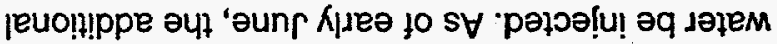

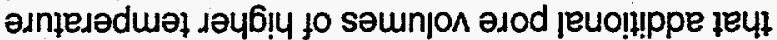

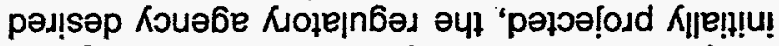

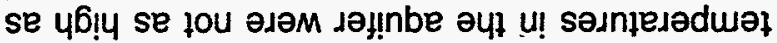

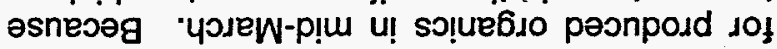

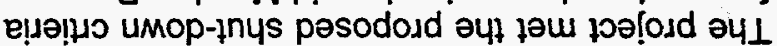

-spuepuels $\forall d \exists$ әाqeidosos of

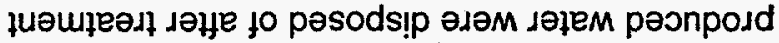

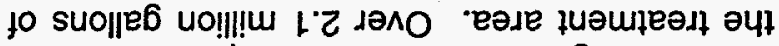

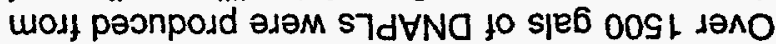

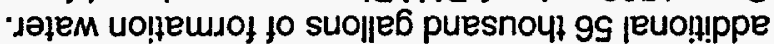
ue jo jenouəs e u! pəunsal bu!̣dund jeuo!!! ppe

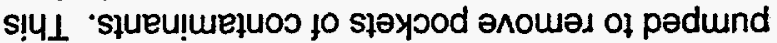




\begin{tabular}{|c|c|c|}
\hline $\begin{array}{l}\text { Program/Project Identification No. } \\
\qquad \text { DE-FC2 |-93MC30 | } 27\end{array}$ & $\begin{array}{l}\text { ProgramiProject TItle } \\
\text { TASK O I } 5 \\
\text { IN SITU TREATMENT OF MANUFACTURED GAS } \\
\text { PLANT CONTAMINATED SOILS } \\
\text { DEMONSTRATION PROGRAM }\end{array}$ & $\begin{array}{l}\text { Peporting Period } \\
10 / 1 / 96 \text { through } 12 / 31 / 96\end{array}$ \\
\hline \multirow{2}{*}{\multicolumn{2}{|c|}{$\begin{array}{l}\text { Name and Address } \\
\text { WESTERN RESEARCH INSTITUTE } \\
365 \text { NORTH NINTH STREET } \\
\text { LARAMIE, WYOMING } 82070\end{array}$}} & $\begin{array}{l}\text { ProgramiProject Start Date } \\
\text { MARCH 26, } 1993\end{array}$ \\
\hline & & $\begin{array}{l}\text { Completion Date } \\
\text { MARCH 25, } 1997\end{array}$ \\
\hline
\end{tabular}

\begin{tabular}{|c|c|c|}
\hline \multicolumn{3}{|c|}{ PROJECT FUNDINO HISTORY } \\
\hline & USDOE & SPONSOR(S) \\
\hline $\begin{array}{l}\text { FY } 1003 \\
\text { FUNDINO }\end{array}$ & 285,280 & \\
\hline $\begin{array}{l}\text { FY } 1004 \\
\text { FUNDINO }\end{array}$ & & 887.072 \\
\hline $\begin{array}{l}\text { FY } 1095 \\
\text { FUNDINO }\end{array}$ & & 567.000 \\
\hline $\begin{array}{l}\text { FY } 1008 \\
\text { FUNDIMO }\end{array}$ & 120.000 & 126,451 \\
\hline $\begin{array}{l}\text { FY } 1007 \\
\text { FUNDINO }\end{array}$ & & \\
\hline $\begin{array}{l}\text { Prouect } \\
\text { Fundimo } \\
\text { TO DATE }\end{array}$ & 405.280 & 1.360 .523 \\
\hline
\end{tabular}
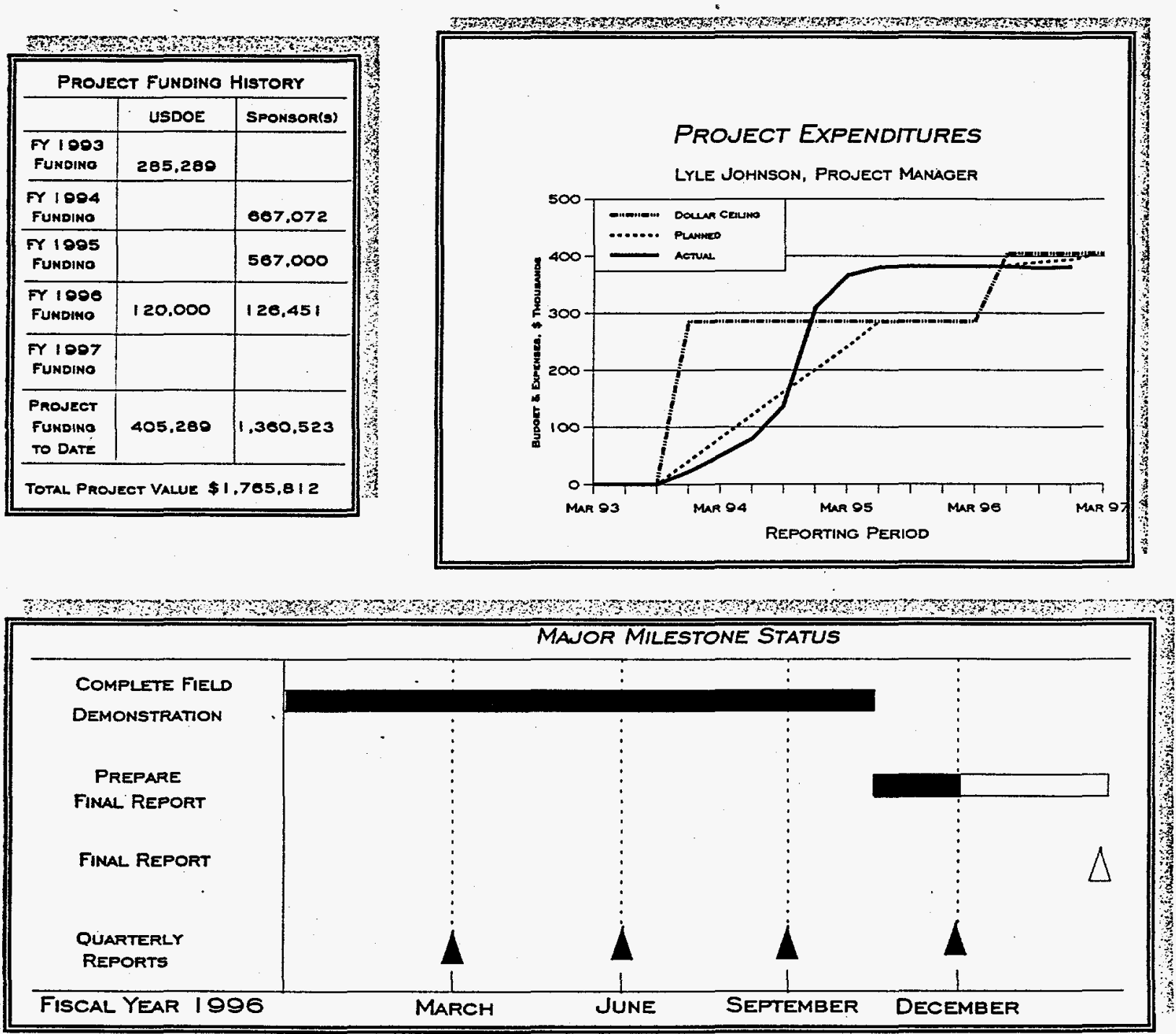

THE PROJECT COSPONSOR HAS ADDED ADDITIONAL CASH TO THE PROJECT RAISING THEIR TOTAL CONTRIBUTION TO $\$ 1,360,523$.

\begin{tabular}{|l|l|l|}
\hline Signature of Recipient and Date & $1 / 27 / 97$ & Signature of USDOE Reviewing Representative and Date \\
\hline$\varepsilon \&$ Bredus.
\end{tabular}




\begin{tabular}{|c|c|c|}
\hline $\begin{array}{c}\text { Task } \\
16\end{array}$ & $\begin{array}{l}\text { Development and Demonstration } \\
\text { of a Wood-Fired Gas Turbine System }\end{array}$ & $\begin{array}{l}\text { Status } \\
\text { On Stand-by }\end{array}$ \\
\hline \multicolumn{3}{|c|}{$\begin{array}{c}\text { Sponsors } \\
\text { Power Generating Inc. and Office of Conservation and Renewable Energy, } \\
\text { US Department of Energy }\end{array}$} \\
\hline \multicolumn{3}{|c|}{ Reporting Period: October 1 through December 31, 1996} \\
\hline \multicolumn{3}{|c|}{ Background } \\
\hline \multicolumn{3}{|c|}{$\begin{array}{l}\text { Development of a means to use inexpensive solid fuels for electrical power generation and thermal } \\
\text { energy has the double benefit of providing low-cost energy and utilization of an otherwise possibly } \\
\text { unused resource. Power Generating Inc. has patented a unique, direct-fired gas turbine power } \\
\text { system that could be operated on such fuels. The system is expected to operate at thermal } \\
\text { efficiencies in excess of } 70 \% \text { through full utilization of the electrical and thermal energy generated. } \\
\text { Problems generally inherent in such systems are overcome by the unique design of this system and } \\
\text { by close control of fuel specifications and operating procedures. WRI is working on the detailed } \\
\text { design of a demonstration unit. When designed, a } 425 \mathrm{kilowatt} \text { power system will be constructed } \\
\text { and tested on a clean wood fuel. Immediately following the wood testing, the system will be } \\
\text { reconfigured and operated on a low-ash coal. }\end{array}$} \\
\hline
\end{tabular}

\section{Task Objectives}

The goal of this project is to confirm the technical and economic viability of operating a direct-fired gas turbine power system on solid fuel. Specific objectives are:

- Refine and finalize the engineering design for the prototype PGI Power System.

- Prove the conceptual and technical feasibility of operating a direct-fired gas turbine power system on solid fuels.

- Confirm the operating characteristics of the PGI Power System.

- Verify the efficiency and economic potential of the PGI Power System.

- Evaluate the potential environmental impact of the PGI Power System.
- Develop recommendations for additional R\&D work on the use of solid fuels in direct-fired gas turbine power systems.

\section{Quarter Objective}

Maintain the plant in cold standby until PGI can secure funds for continuation of the project.

\section{Accomplishments}

The plant is being kept in cold standby while the industrial partner is attempting to raise the funds for continuation of the project.

\section{Activities for Next Quarter}

When required funds are made available, the plant will be restarted and testing will resume. 


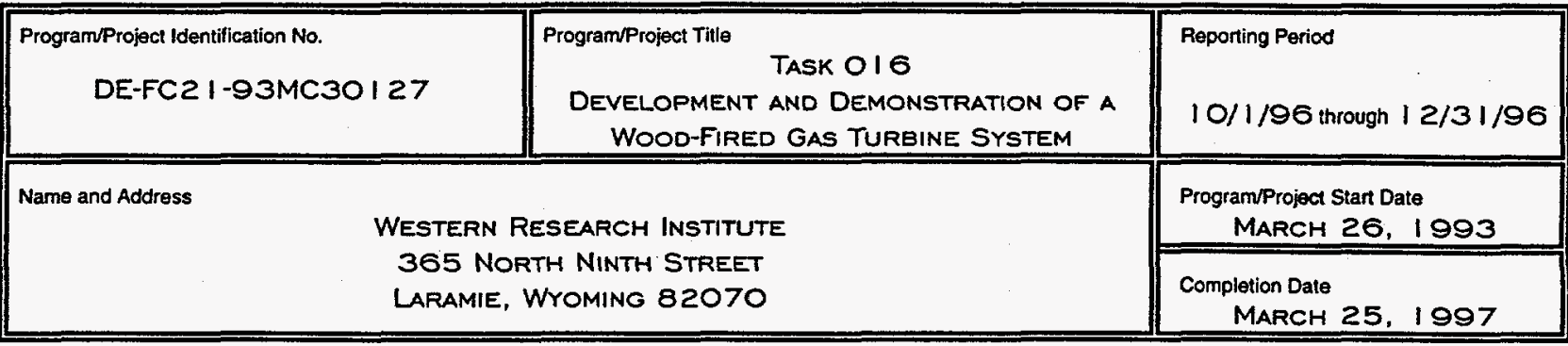

\begin{tabular}{|c|c|c|}
\hline \multicolumn{3}{|c|}{ PROJECT FUNDINO HISTORY } \\
\hline & USDOE & SPONSOR(s) \\
\hline $\begin{array}{l}\text { FY } 1003 \\
\text { FUNDINO }\end{array}$ & & , \\
\hline $\begin{array}{l}\text { FY } 1004 \\
\text { FUNDINO }\end{array}$ & 673,434 & $1,313.584$ \\
\hline $\begin{array}{l}\text { FY } 1005 \\
\text { FUNDIMO }\end{array}$ & 742.800 & 900.400 \\
\hline $\begin{array}{l}\text { FY } 1000 \\
\text { FUNDINA }\end{array}$ & & \\
\hline $\begin{array}{l}\text { FY } 1007 \\
\text { FUNDINO }\end{array}$ & & \\
\hline $\begin{array}{l}\text { PROJECT } \\
\text { FUNDINO } \\
\text { TO DATE }\end{array}$ & $1,416,234$ & $2,303,084$ \\
\hline
\end{tabular}

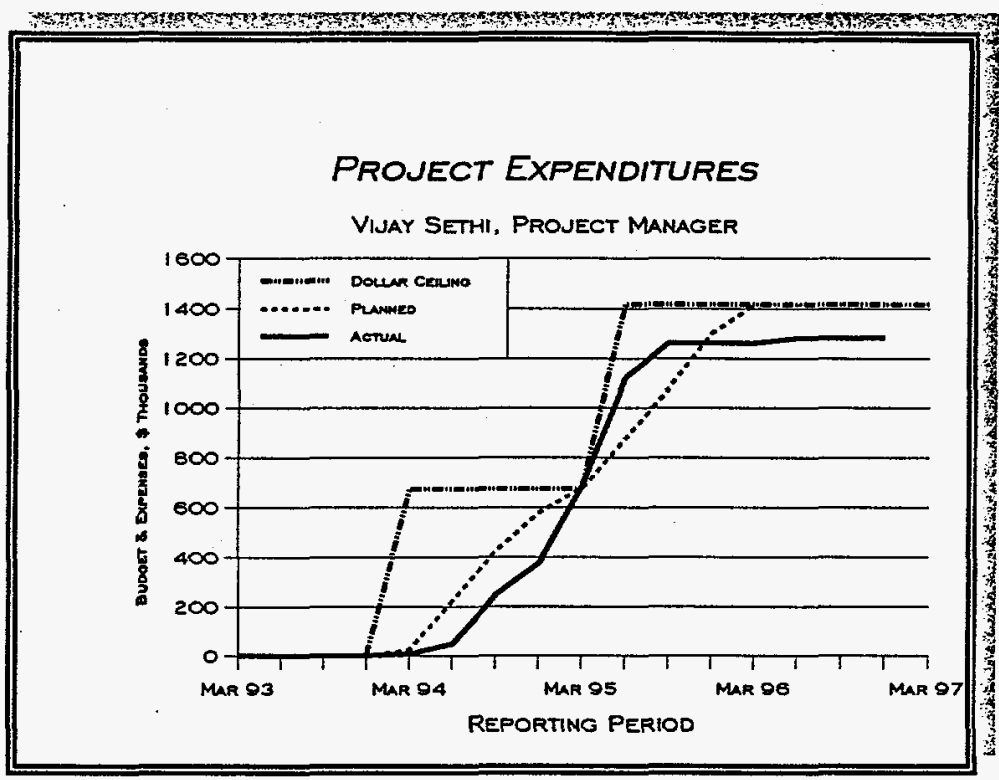

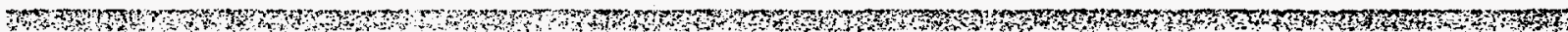

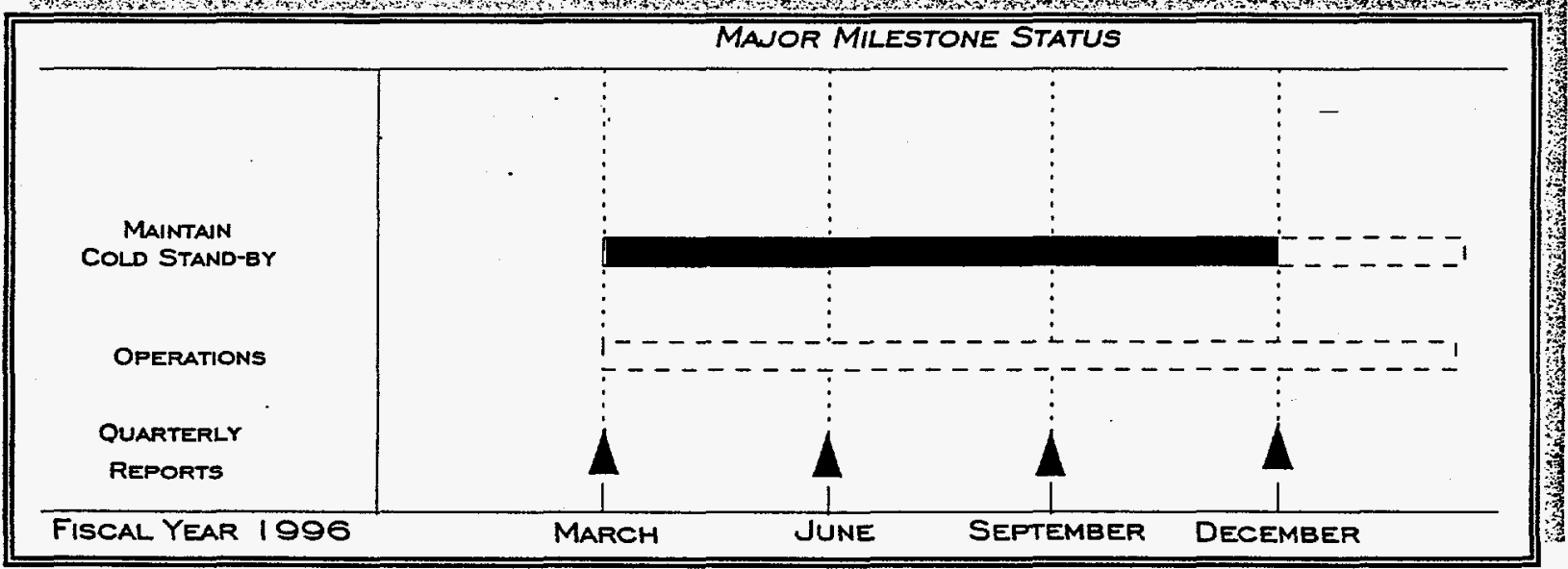

COSPONSOR FUNDING IN FY 95 CONSISTED OF \$840,200 CASH AND \$150,200 IN-KIND

COSPONSOR FUNOING IN FY 94 CONSISTED OF $\$ 832,584$ CASH AND $\$ 481,000$ IN-KIND

Signature of Recipient and Date


Task

17
Solid State NMR Analysis of Mowry Formation Shale from Different Sedimentary Basins
Status Completed

\section{Sponsors \\ University of Wyoming and Gas Research Institute}

Reporting Period: October 1 through December 31, 1996

\section{Background}

New approaches and supporting technology are needed to reverse the diminishing returns from oil and gas exploration in the United States. The discovery of subsurface fluid or pressure chambers has the potential to delineate a new class of hydrocarbon traps, thereby revitalizing interest in domestic exploration. The University of Wyoming has a research project to develop a conceptual model of the formation, distribution, and destruction of pressure chambers and seals in sedimentary basins. A key to understanding the diagenetic and maturational behavior is knowledge of the organic carbon structure of the kerogen in petroleum source rocks and how the kerogen structure changed during petroleum generation. As a part of this project, WRI is performing solid-state NMR measurements to provide information on the diagenesis and maturation of petroleum source rocks. The material being studied in this task is Mowry Formation shale from sedimentary basins.

\section{Task Objective}

The objectives of this JSR project are to use solidstate nuclear magnetic resonance (NMR) methods to study the maturation of source rocks obtained from various depths of burial and from different sedimentary basins.

\section{Quarter Objective}

Complete final topical report.

\section{Accomplishments}

A draft copy of the final topical report was completed.

\section{Activities for Next Quarter}

Project is completed; no further work is planned 


\begin{tabular}{|c|c|c|}
\hline $\begin{array}{l}\text { ProgramProject Identification No. } \\
\qquad \text { DE-FC2 I-93MC30 I } 27\end{array}$ & $\begin{array}{l}\text { ProgramProject TIIle } \\
\text { TASK O } 17 \\
\text { ANALYSIS OF MOWRY FORMATION SHALE } \\
\text { FROM DIFFERENT SEDIMENTARY BASINS }\end{array}$ & $\begin{array}{l}\text { Reporting Period } \\
10 / 1 / 96 \text { through } 12 / 31 / 96\end{array}$ \\
\hline \multirow{2}{*}{\multicolumn{2}{|c|}{$\begin{array}{l}\text { ESEARCH INSTITUTE } \\
\text { IH NINTH STREET } \\
\text { MOMING } 82070\end{array}$}} & $\begin{array}{l}\text { Program/Project Start Date } \\
\text { MARCH 26, } 1993\end{array}$ \\
\hline & & $\begin{array}{l}\text { Completion Date } \\
\text { MARCH 25, } 1997\end{array}$ \\
\hline
\end{tabular}

\begin{tabular}{|c|c|c|}
\hline \multicolumn{3}{|c|}{ PROJECT FUNDING HISTORY } \\
\hline & USDOE & SPONSOR(s) \\
\hline $\begin{array}{l}\text { FY } 1003 \\
\text { FUNDIMO }\end{array}$ & & o \\
\hline $\begin{array}{l}\text { FY } 1004 \\
\text { FUNDINO }\end{array}$ & 30,064 & 30,000 \\
\hline $\begin{array}{l}\text { FY } 1005 \\
\text { FUNDINO }\end{array}$ & 30.000 & 30,000 \\
\hline $\begin{array}{l}\text { FY } 1008 \\
\text { FUNDINO }\end{array}$ & & \\
\hline $\begin{array}{l}\text { FY } 1007 \\
\text { FUNOINO }\end{array}$ & & \\
\hline $\begin{array}{l}\text { PROJECT } \\
\text { FUNDINO } \\
\text { TO DATE }\end{array}$ & 00.084 & 00.000 \\
\hline
\end{tabular}
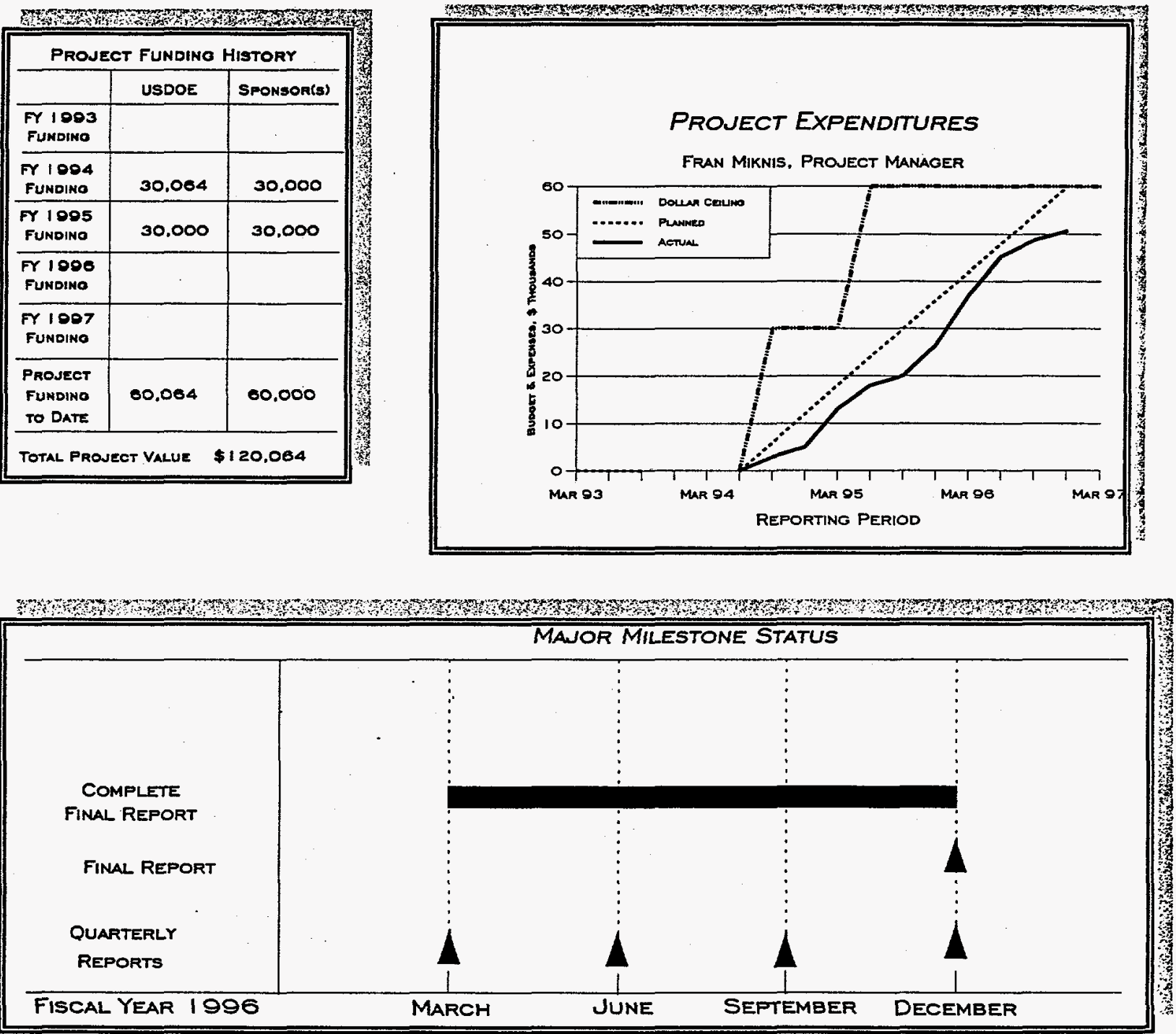

COSPONSOR FUNDING IN FY 95 CONSISTED OF $\$ 30,000 \mathrm{CASH}$

COSPONSOR FUNDING IN FY 94 CONSISTED OF $\$ 30,000$ CASH

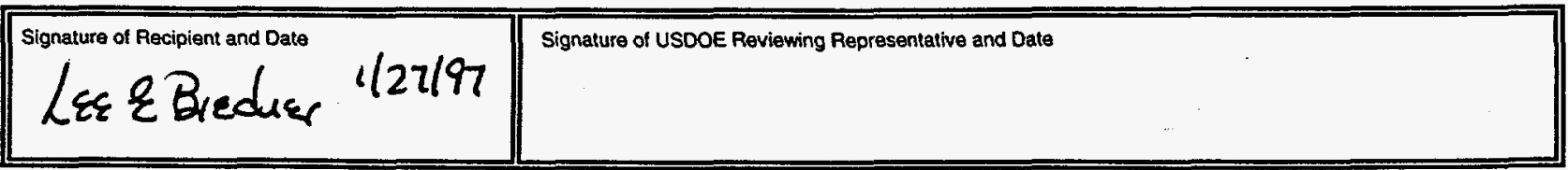




\section{Task Objective}

The task objective is to evaluate the methods available and to develop methods to control or eliminate the production of acid in the Stockett/Sand Coulee mine area.

\section{Quarter Objectives}

Investigations concerning the establishment of coatings on the acid forming materials will be initiated. A selected number of the core samples will be analyzed to determine the extent of the acid-forming reaction zone in the Number 6 mine. The monitoring program will continue at the mine site.

\section{Accomplishments}

On-site water monitoring is on-going. Weathering tests were conducted using the Soxhlet apparatus and humidity cells. The results are currently being evaluated. A column study showing the impact of underground placement of acid-neutralizing materials on acid mine drainage was initiated.

\section{Activities for Next Quarter}

Investigations concerning the establishment of coatings on the acid forming materials will continue. Weathering tests evaluating pyrite coatings will be conducted using a modified Soxhlet apparatus. A selected number of the core samples will be analyzed. The monitoring program will continue at the mine site. 


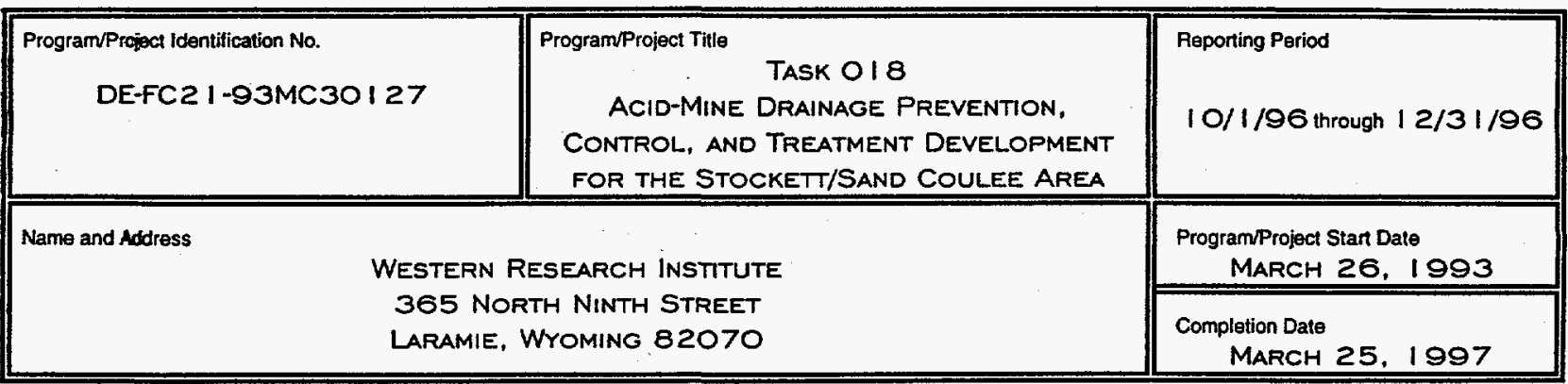

\begin{tabular}{|c|c|c|}
\hline \multicolumn{3}{|c|}{ PROJECT FUNDINO HISTORY } \\
\hline & USDOE & SPONSOR(S) \\
\hline \multicolumn{3}{|l|}{$\begin{array}{l}\text { FY } 1003 \\
\text { Fundino }\end{array}$} \\
\hline $\begin{array}{l}\text { FY } 1004 \\
\text { FUNDINO }\end{array}$ & 110,865 & 120.000 \\
\hline $\begin{array}{l}\text { FY } 1005 \\
\text { FundINE }\end{array}$ & 01.403 & $\infty 0,845$ \\
\hline \multicolumn{3}{|l|}{$\begin{array}{l}\text { FY } 1008 \\
\text { FUMDINO }\end{array}$} \\
\hline \multicolumn{3}{|l|}{$\begin{array}{l}\text { FY } 1007 \\
\text { FUNDINO }\end{array}$} \\
\hline $\begin{array}{l}\text { PROJECT } \\
\text { FUNDINO } \\
\text { TO DATE }\end{array}$ & 211.088 & 210,845 \\
\hline
\end{tabular}
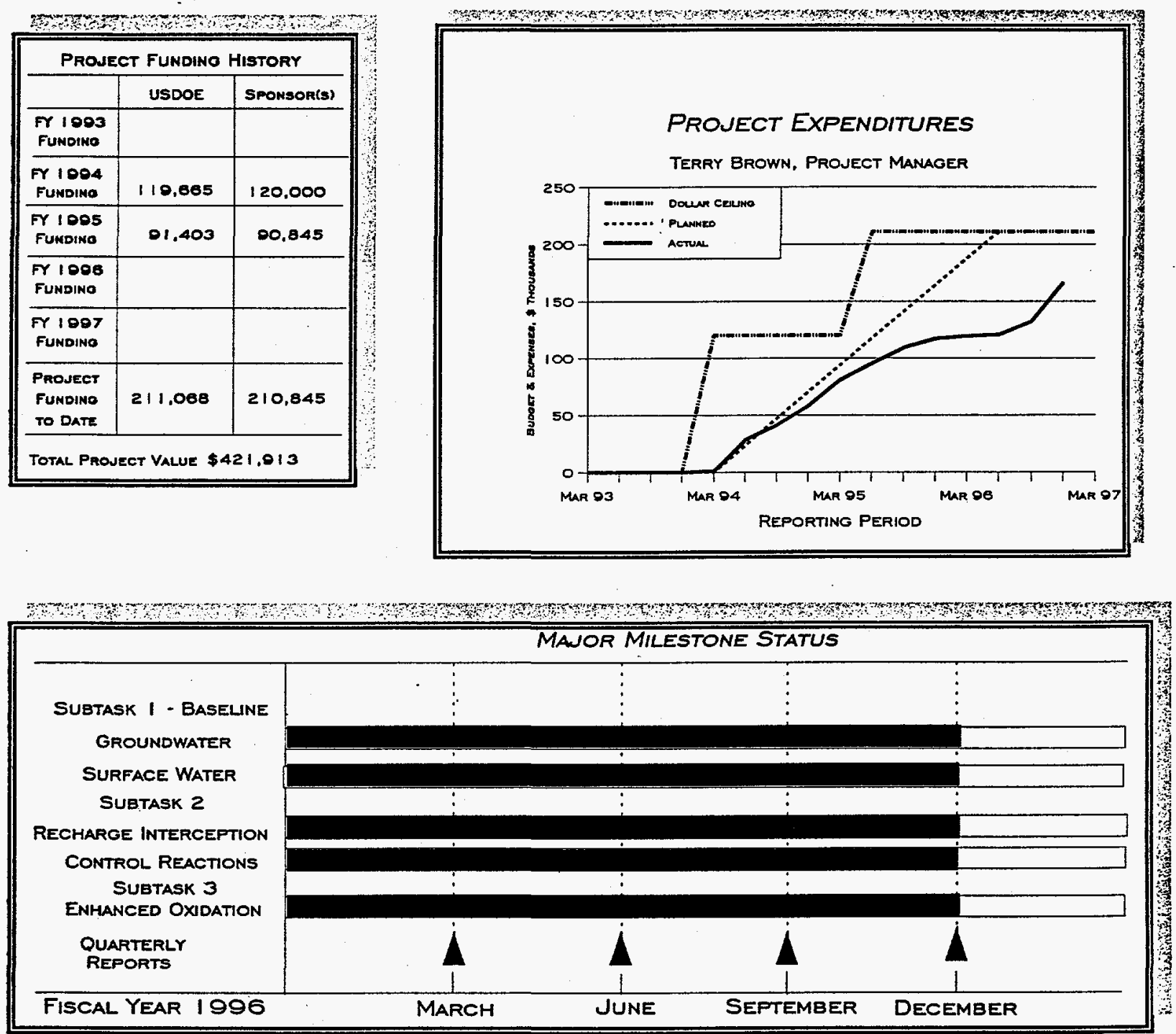

COSPONSOR FUNDING IN FY 95 CONSISTED OF $\$ 90,845$ IN-KIND

COSPONSOR FUNDING IN FY 94 CONSISTED OF $\$ 120,000$ IN-KIND

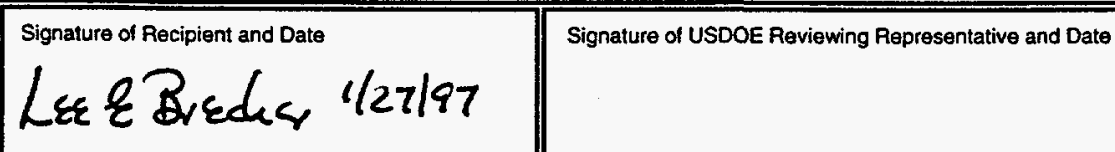




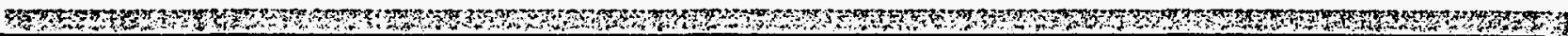

\begin{tabular}{|c|c|c|}
\hline $\begin{array}{c}\text { Task } \\
19\end{array}$ & $\begin{array}{c}\text { PERF Dispersion Modeling Project } \\
\text { Phase } 2 \\
\text { Major Field Demonstration }\end{array}$ & $\begin{array}{l}\text { Status } \\
\text { Ongoing }\end{array}$ \\
\hline \multicolumn{3}{|c|}{$\begin{array}{c}\text { Sponsor } \\
\text { Petroleum Environmental Research Forum } \\
\text { (Allied Signal Corporation, Amoco Corporation, Chevron Research and Technology Co., CITGO } \\
\text { Petroleum Corporation, Clark Oil and Refining Co., Exxon Research and Engineering Co., } \\
\text { Marathon Corporation, Mobil Research and Development Co., Phillips Petroleum Co., and Shell } \\
\text { Research and Development Company) }\end{array}$} \\
\hline \multicolumn{3}{|c|}{ Reporting Period: October 1 through December 31, 1996} \\
\hline \multicolumn{3}{|c|}{ Background } \\
\hline \multicolumn{3}{|c|}{$\begin{array}{l}\text { WRI and Petroleum Environmental Research Forum (93-16) are assessing the application of newly } \\
\text { developed mathematical models for predicting dense gas dispersion by testing the models against } \\
\text { the experimental results of large scale field simulations of chemical spills. The PERF and WRI are } \\
\text { conducting field scale tests of dense gas dispersion in order to validate the models and to provide } \\
\text { the hydrocarbon and chemical industries with information needed to conduct risk management } \\
\text { assessments. Major components of the tests are; source emissions release system, meteorology } \\
\text { data analyses and meteorology instrumentation, and the array configuration. The WRI } 1993 \\
\text { HAZMAT spill test results, wind tunnel tests, and model results were used to aid in the design of the } \\
\text { dispersion grid dimensions, sensor location, and test operation. }\end{array}$} \\
\hline
\end{tabular}

\section{Task Objective}

Implement and conduct the PERF 93-16 tests to the design specification and collect data for gas releases in the simulated petroleum refinery/tank farm under neutral and stable atmospheric conditions

\section{Quarter Objectives}

This quarter's primary objective has been to arrange funding from EPA and the PERF to support the data processing and analysis of the acquired data sets.

\section{Accomplishments}

No funding has been provided with which to complete the technical work.

\section{Activities for Next Quarter}

Quality assurance for the test operations is completed. The final report will be prepared upon receipt of the remaining funding from EPA and the PERF. 


\begin{tabular}{|c|c|c|}
\hline $\begin{array}{l}\text { Program/Project Identification No. } \\
\text { DE-FC2 1-93MC } 30127\end{array}$ & $\begin{array}{c}\text { ProgramProject Tite } \\
\text { TASK O } 19 \\
\text { PERF DISPERSION MODELING PROJECT } \\
\text { PHASE } 2 \\
\text { MAJOR FIELD DEMONSTRATION }\end{array}$ & $\begin{array}{l}\text { Reporting Period } \\
10 / 1 / 96 \text { through } 12 / 31 / 96\end{array}$ \\
\hline \multirow{2}{*}{\multicolumn{2}{|c|}{$\begin{array}{l}\text { Name and Address } \\
\text { WESTERN RESEARCH INSTITUTE } \\
365 \text { NORTH NINTH STREET } \\
\text { LARAMIE, WYOMING } 82070\end{array}$}} & $\begin{array}{l}\text { ProgramProject Start Date } \\
\text { MARCH } 26,1993\end{array}$ \\
\hline & & $\begin{array}{l}\text { Completion Date } \\
\text { MARCH 25, } 1997\end{array}$ \\
\hline
\end{tabular}

\begin{tabular}{|c|c|c|}
\hline \multicolumn{3}{|c|}{ PROJECT FUNDINO HISTORY } \\
\hline & USDOE & SPONBOR(S) \\
\hline \multicolumn{3}{|l|}{$\begin{array}{l}\text { FY } 1003 \\
\text { FUNDINO }\end{array}$} \\
\hline \multicolumn{3}{|l|}{$\begin{array}{c}\text { FY } 1004 \\
\text { FUNDINO }\end{array}$} \\
\hline $\begin{array}{l}\text { FY } 1005 \\
\text { FUNDINO }\end{array}$ & 502,124 & 945,330 \\
\hline \multicolumn{3}{|l|}{$\begin{array}{l}\text { FY } 1000 \\
\text { FUNDINO }\end{array}$} \\
\hline \multicolumn{3}{|l|}{$\begin{array}{l}\text { FY } 1007 \\
\text { FUNDINO }\end{array}$} \\
\hline $\begin{array}{l}\text { PROJECT } \\
\text { FUNdINO } \\
\text { TO DATE }\end{array}$ & 502.124 & 045,330 \\
\hline
\end{tabular}
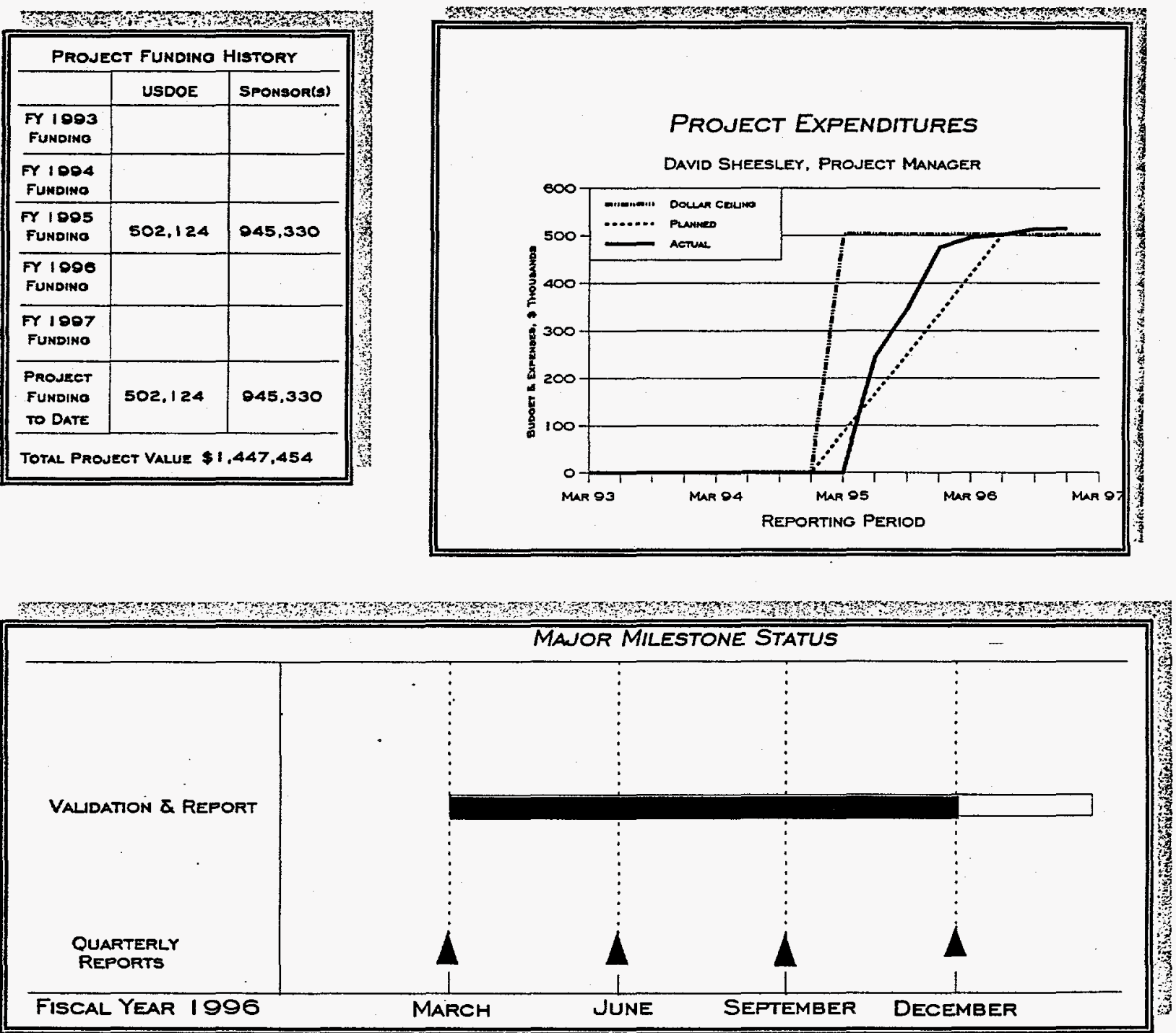

COSPONSOR FUNDING IN FY 95 CONSISTED OF $\$ 315,000 \mathrm{CASH}$ AND $\$ 630,330$ IN-KIND

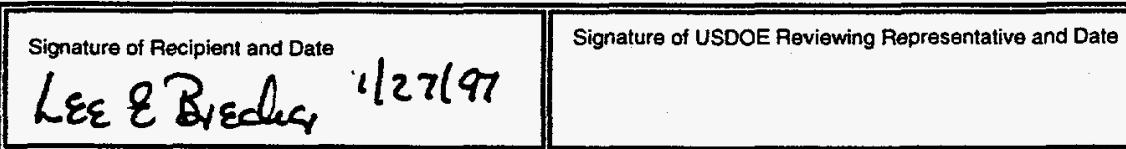




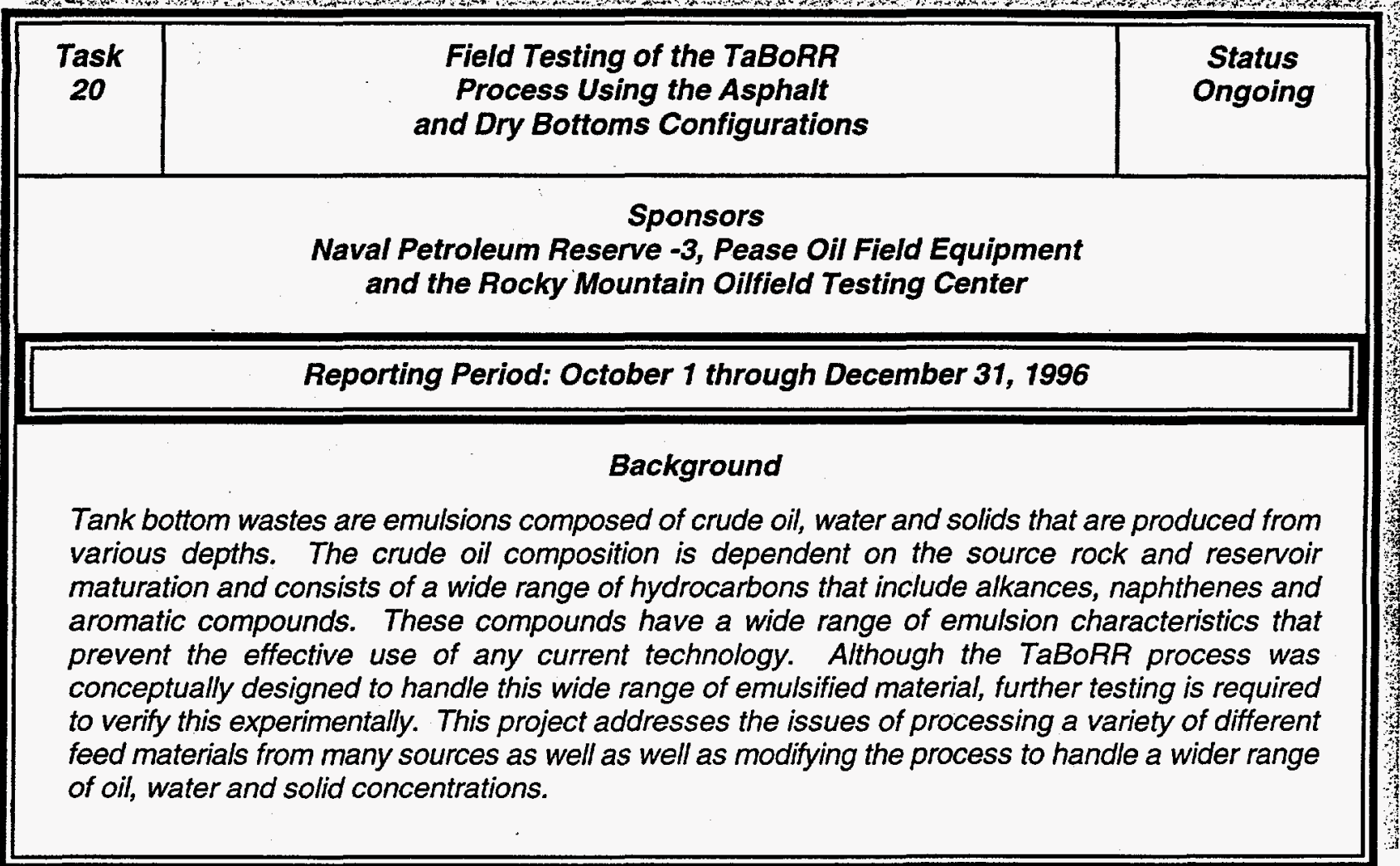

\section{Task Objectives}

The task objectives are to:

- $\quad$ Perform modifications to the process to allow for handling larger water concentrations and larger solid sizes present in the feed material;

- Test and operate the unit using a variety of feed materials;

- Determine the feasibility of using the bottoms material as a road material;

- Perform modifications to the process to convert the bottoms into solid material and use the gaseous hydrocarbons as a fuel source for the process; and

- Test and operate the unit to ensure environmental compliance and verify process economics

\section{Quarter Objectives}

Complete plant shakedown. Operate the plant using process material already at WRI's premises to develop a mass and energy balance. Develop a design for a carbonizer to thermally convert waste from the process into a solid material.

\section{Accomplishments}

The heat tracing and insulation of fluid carrying lines was completed. These activities were completed concurrently with plant shakedown.

The plant shakedown activities were continued. As stated in a previous report, approximately 340 bbl of feed material was received from Pease Oil Field Equipment in three truck loads. The material was analyzed for its water and solids content and contained approximately $0.3 \%$ solids and about $20 \%$ water. This material was used for debugging the plant equipment under cold flow conditions.

Plant shakedown began in early October. The flash step of the process worked very well, 
however some modifications were required to efficiently direct the flash overheads to the flare.

Integrated plant testing including stripper operation began during mid-October. Early operations quickly showed that some of the product recovery system was not operating as expected. Extensive modifications were undertaken to remedy these deficiencies.

The plant was successfully operated on October 29,1996 for a period of about $20 \mathrm{hrs}$. Since then nearly 11,000 gal. of material have been processed in the facility. Recovery rates achieved to date have ranged from 40 to 65 volume percent. Further testing using Pease Oil Field Equipment material is continuing.
Samples of the product recovered were sent to area refineries for testing and found to be acceptable as feed stock at a premium price.

The carbonizer design has been finalized and the equipment is being procured and fabricated.

\section{Activities for Next Quarter}

Complete product characterization from Pease Oil Field Equipment material. Procure material from a different source and continue plant testing. 


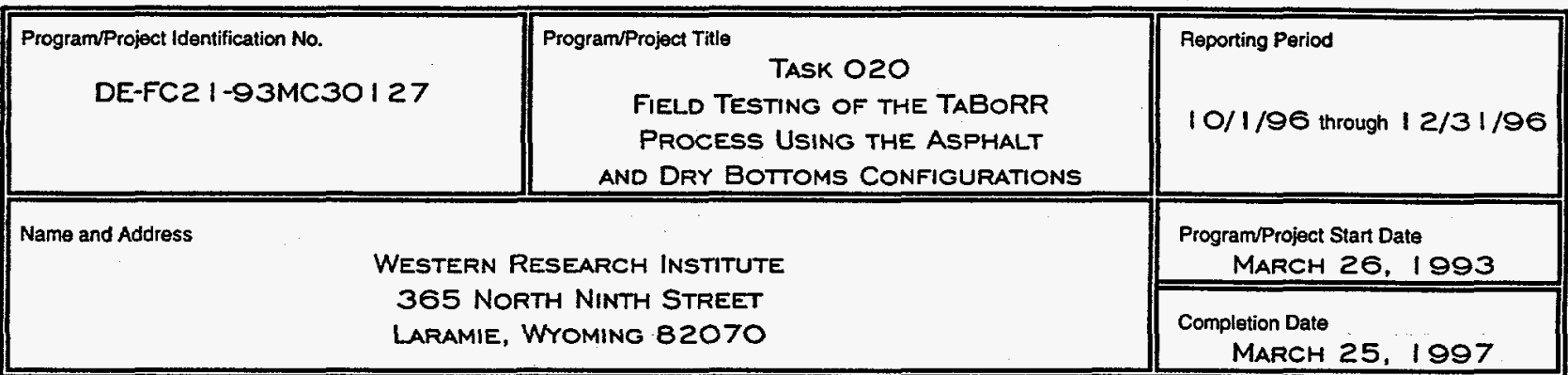

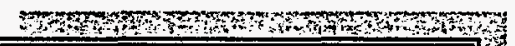

\begin{tabular}{|l|l|l|}
\hline \multicolumn{2}{|c|}{ PROJECT FUNDING HISTORY } \\
\hline $\begin{array}{l}\text { FY } 1003 \\
\text { FUNDINO }\end{array}$ & USDOE & SPONSORIS) \\
\hline $\begin{array}{l}\text { FY } 1004 \\
\text { FUNDINO }\end{array}$ & & \\
\hline $\begin{array}{l}\text { FY } 1095 \\
\text { FUNDINO }\end{array}$ & & \\
\hline $\begin{array}{l}\text { FY } 1006 \\
\text { FUNDINO }\end{array}$ & 285.000 & 285.415 \\
\hline $\begin{array}{l}\text { FY } 1007 \\
\text { FUNDINO }\end{array}$ & & \\
\hline $\begin{array}{l}\text { PROJECT } \\
\text { FUMDINO } \\
\text { TO DATE }\end{array}$ & 285.000 & 285.415 \\
\hline TOTAL PROJECT VALUE $\$ 570.415$ \\
\hline
\end{tabular}
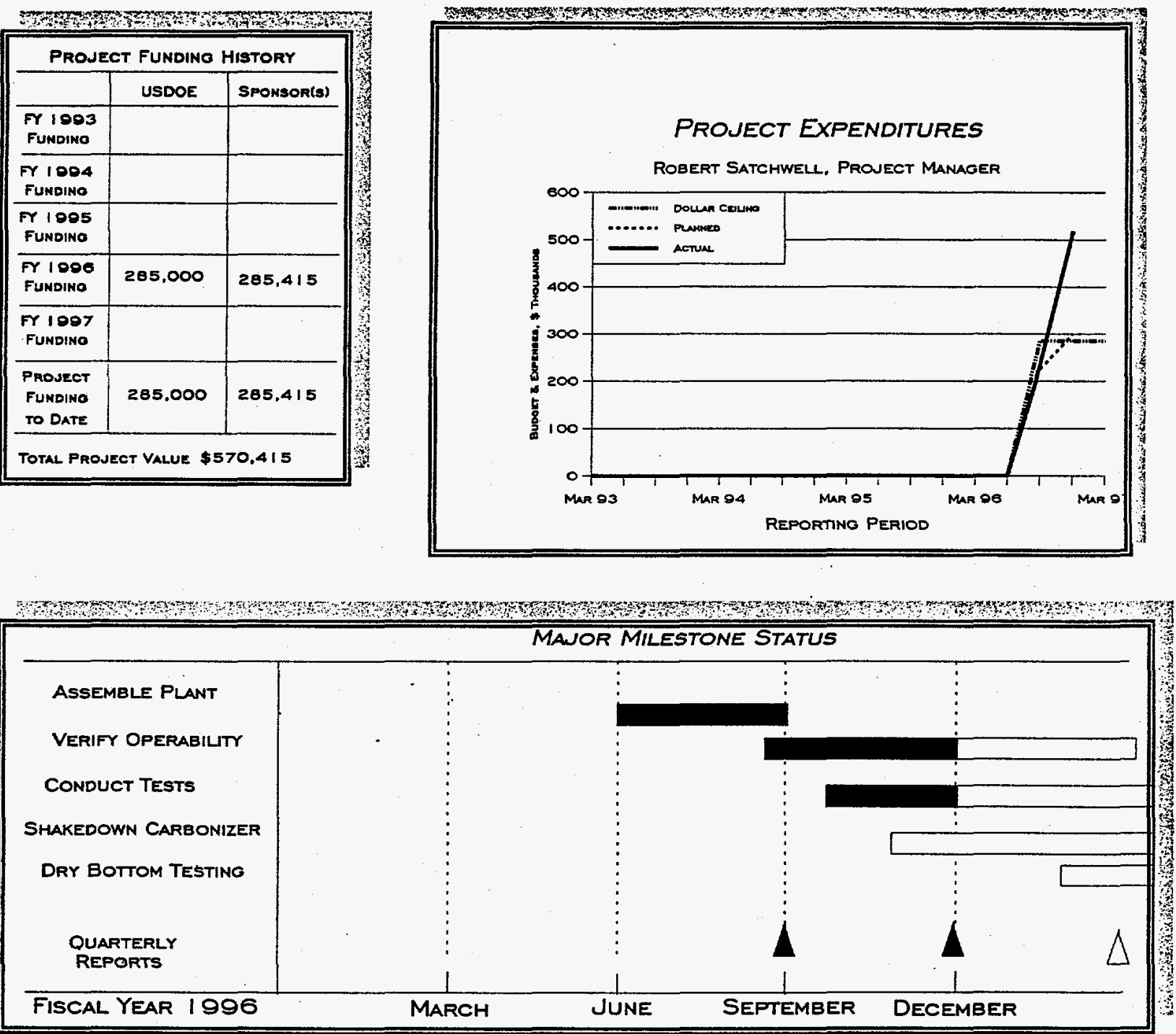

COSPONSOR FUNDING IN FY 96 CONSISTED OF $\$ 285.415$ IN-KIND

\begin{tabular}{|c|c|}
\hline Signature of Recipient and Date & Signature of USDOE Reviewing Representative and Date \\
\hline
\end{tabular}


Task

21
Validation of a New

Soil VOC Sampler
Status

Ongoing

\section{Sponsor \\ En Chem Incorporated}

Reporting Period: October 1 through December 31, 1996

\section{Background}

WRI is providing technical support directed at achieving national acceptance for the EnCore sampling device to enhance its market acceptance by both the regulatory community and environmental contract firms that are responsible for the evaluation of VOC contamination at sites throughout the country. One version of the EnCore sampler is accepted for use by the state of Wisconsin. It is a stainless steel device that requires cleaning after use. En Chem is developing a disposable version of the sampler which will lower the cost of use and enhance its acceptance. WRI is evaluating the operation of the stainless steel device. Following successful evaluation, WRI will approach the American Society for Testing and Materials (ASTM) to initiate a process for method preparation and approval in ASTM format. The ASTM approval process will be initiated with the goal of providing national acceptance of the EnCore samplers. WRI will also provide technical support to En Chem in the development of a disposable plastic version of the EnCore sampler.

\section{Task Objective}

Western Research Institute is facilitating national acceptance of the EnCore ${ }^{T M}$ soil volatile organic compound (VOC) sampling device by conducting product tests, method development, and method validation activities.

\section{Quarter Objectives}

- $\quad$ Sign the contract with the corporate cosponsor En Chem, Inc.

- $\quad$ Attend the national ASTM meeting in October and begin ASTM method approval activities.

- Evaluate the use and performance of the EnCore soil VOC sampling device.

\section{Accomplishments}

The contract with the corporate cosponsor was signed on October 4, 1996.

- The national ASTM meeting in New Orleans was attended in October to begin the process of ASTM approval for a new ASTM practice describing the use of the EnCore sampler. The title of the new practice was selected at the meeting to be "Standard Practice for Using a Coring Tube for Sampling and Storing Soil Samples for Volatile Organic Analysis". Work on developing the draft practice was started.

- WRI will also participate in the revision of ASTM D-4547, "Standard Practice for Sampling Waste and Soils for Volatile Organics". Revision of this method in conjunction with development of a new practice sill be ideal so the new practice can be referenced in D-4547. The revision of $D-4547$ will be included in the EPAIASTM Accelerated Standards Program.

- Issues related to testing of the EnCore sampler were discussed in telephone conversations with $\mathrm{Al} \mathrm{Hewitt} \mathrm{at} \mathrm{the} \mathrm{U.S.}$ Army Cold Regions Laboratory, who will be assisting in the EnCore evaluation effort. 
The experiments needed for the new ASTM practice documentation were discussed in conference calls with En Chem, Inc. A detailed experimental plan and tentative schedule was developed with input from En Chem.

- Eleven 5-gram prototype stainless steel EnCore samplers were ordered from the fabricator. These will be used in the practice development experiments.

\section{Activities for Next Quarter}

- Write a draft of the new practice.

- Perform experiments to verify the performance of the stainless steel prototype EnCore sampling devices. Incorporate the results in to the new practice draft. 


\begin{tabular}{|c|c|c|}
\hline $\begin{array}{l}\text { Program/Project Identification No. } \\
\qquad \text { DE-FC2 I -93MC30 I } 27\end{array}$ & $\begin{array}{l}\text { ProgramProject Tille } \\
\text { TASK O2 I } \\
\text { VALIDATION OF A NEW } \\
\text { SOIL VOC SAMPLER }\end{array}$ & $\begin{array}{l}\text { Peporting Period } \\
10 / 1 / 96 \text { through } 12 / 31 / 96\end{array}$ \\
\hline \multirow{2}{*}{\multicolumn{2}{|c|}{$\begin{array}{l}\text { ESEARCH INSTITUTE } \\
\text { TH NINTH STREET } \\
\text { YYOMING } 82070\end{array}$}} & $\begin{array}{l}\text { Program/Project Start Date } \\
\text { MARCH } 26,1993\end{array}$ \\
\hline & & $\begin{array}{l}\text { Completion Date } \\
\text { MARCH 25, } 1997\end{array}$ \\
\hline
\end{tabular}

\begin{tabular}{|c|c|c|}
\hline \multicolumn{3}{|c|}{ PROJECT FUNDINO HISTORY } \\
\hline & USDOE & SPONSOR(S) \\
\hline $\begin{array}{l}\text { FY } 1003 \\
\text { Fundino }\end{array}$ & & \\
\hline $\begin{array}{l}\text { FY } 1004 \\
\text { FundiNo }\end{array}$ & & \\
\hline $\begin{array}{l}\text { FY } 1005 \\
\text { FUNDINO }\end{array}$ & & \\
\hline $\begin{array}{l}\text { FY } 1008 \\
\text { FUNDINO }\end{array}$ & 50,541 & 62,500 \\
\hline $\begin{array}{l}\text { FY } 1007 \\
\text { FUNDINO }\end{array}$ & & \\
\hline $\begin{array}{l}\text { PROJECT } \\
\text { FUNOINO } \\
\text { TO DATE }\end{array}$ & 50.541 & 82,500 \\
\hline
\end{tabular}
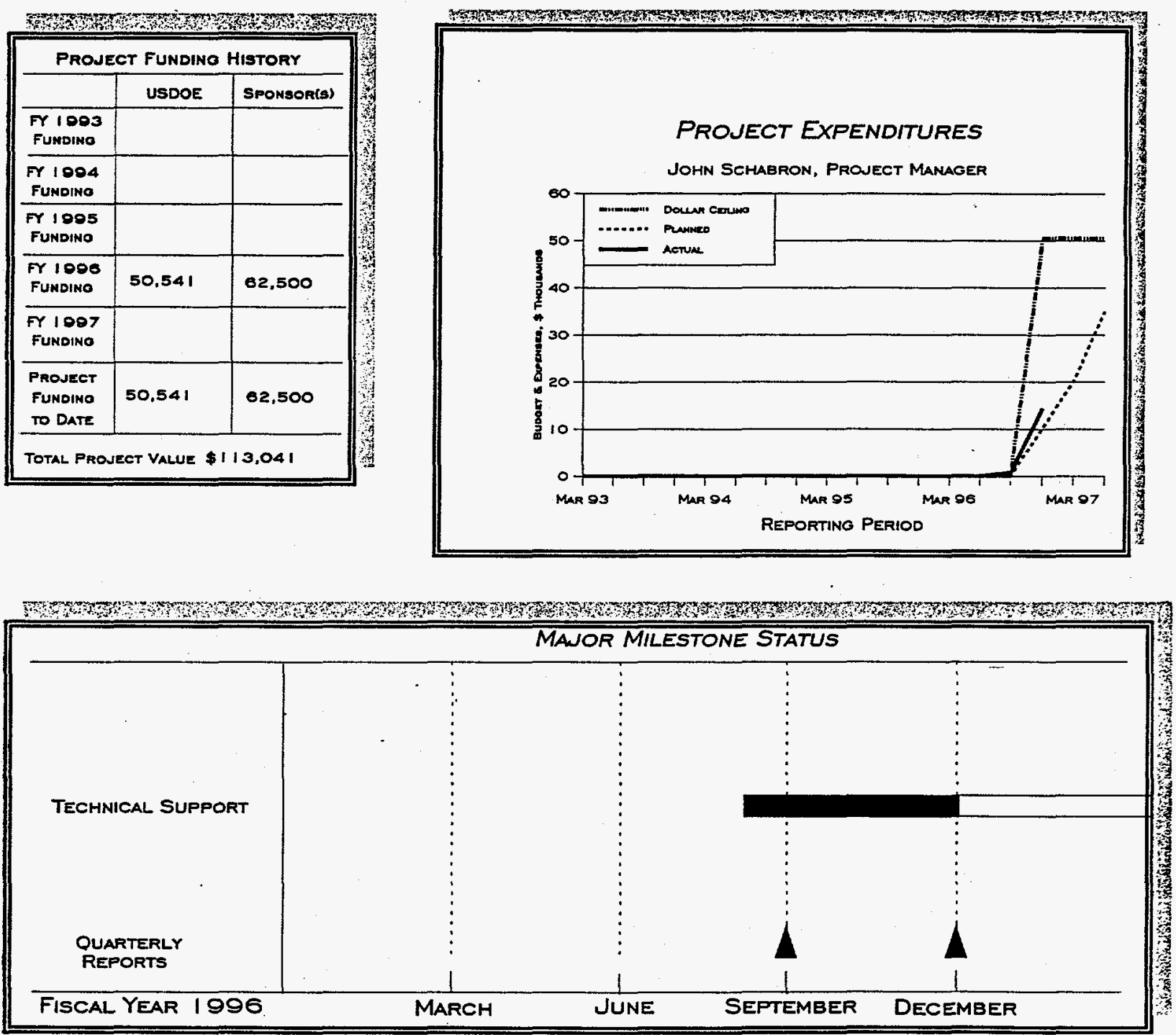

COSPONSOR FUNDING IN FY 96 CONSISTED OF $\$ 12,500$ CASH AND $\$ 50,000$ IN-KIND

Signature of Recipient and Date

